\title{
User Computer System Pilot Project
}

\author{
Edward C. Eimutis
}

September 6, 1989

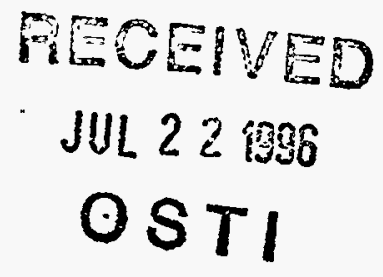

\section{MOUND}

operated by

¿ EGRG MOUND APPLIED TECHNOLOGIES

P.O. Box 3000, Miamisburg, Ohio 45343-3000

for the

U. S. DEPARTMENT OF ENERGY

Contract No. DE-AC04-88DP43495 


\section{DISCLAIMER}

This report was prepared as an account of work spensored by an agency of the United States Government. Nelther the United States Government nor any agency thereof. nor any of their employees. makes any warranty. express or implied. or assumes any legal liability or responsibility for the accuracy. completeness. or usefulness of any infirmation. apparatus. product. or process disclosed. Or represents that its use would not infinge privately owned rights. Reference herein to any spectife commercial product, process. or service by trade name. trademark. manufacturer. or otherwise, does not necessarily constitute or imply its endorsement. recommendation. or favoring by the United States Government or any agency thereof. The views and opinions of authors expressed hereln do not necessarily state or reflect those of the United States Government or any agency thereof. 


\section{DISCLAIMER}

Portions of this document may be illegible in electronic image products. Images are produced from the best available original document. 
MLM-MU-89-69-0001

\section{User Computer System Pilot Project}

Edward C. Eimutis

Issued: September 6, 1989 


\section{Contents}

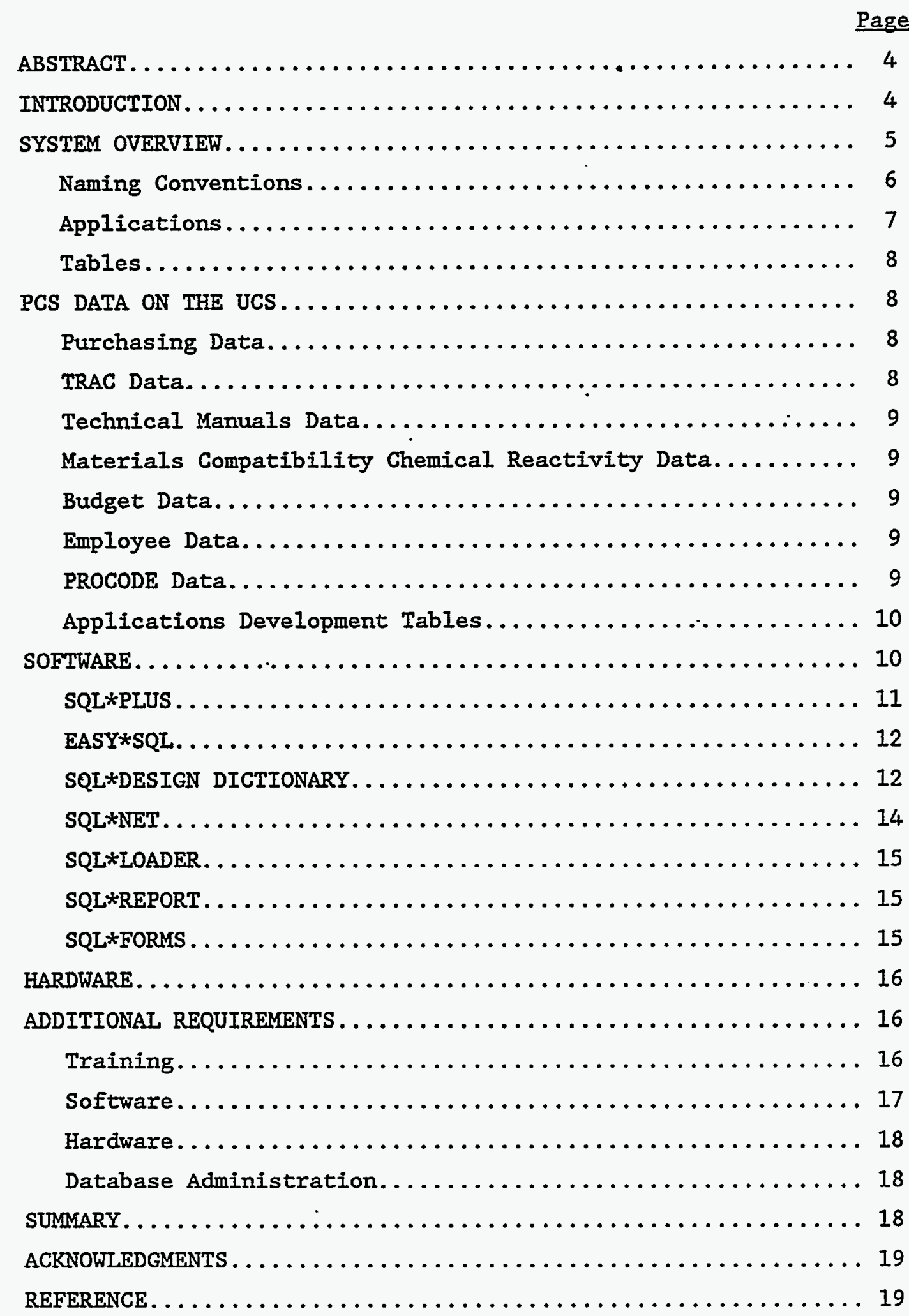


APPENDIX A: LETTER SOLICITING PILOT PARTICIPATION......... 21

APPENDIX B: DESCRIPTION OF IAP TABLES ............... 23

APPENDIX $C$ : ORACLE TABLES, VIEWS, AND SYNONYMS ......... 27

APPENDIX D: SDD ENTITY AND ATTRIBUTE REPORT............ 44

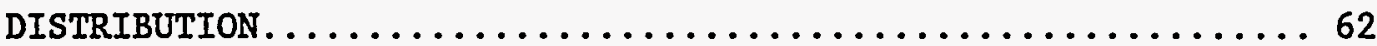




\section{Abstract}

The User Computer System (UCS) is a general purpose unclassified, nonproduction system for Mound users. The UCS pi.lot project was successfully completed, and the system currently has more than 250 users: Over 100 tables were installed on the UCS for use by subscribers, including tables containing data on employees, budgets, and purchasing. In addition, a UCS training course was developed and implemented.

\section{Introduction}

The User Computer System (UCS) was in the planning stages for quite some time. (It was originally called the End User Computer System.) It was first proposed in the Automatic Data Processing (ADP) Long Range Plan dated February 1983. Originally conceived as a decision support processor, it evolved over the years into a database and information support tool. This was a logical progression, as the availability of professional workstations (IBM personal computers) adequately served many decision support functions. However, two functions were still missing: the ability to easily access and manipulate plantwide data and the ability to readily share departmental data. These functions were identified as most important in a survey reported in Mound End User InformationHandling Requirements [1]. The ORACLE product set was selected to meet the stated user requirements.

The initial pilot group comprised 14 persons. These individuals were given tutorials and demonstrations in the use of the ORACLE products on the UCS. References for ORACLE documentation were supplied in the event the users needed additional documentation. The early arrival of an application, time sheets, and the Project Accounting and Control System (PACS) increased the user base to some 150 subscribers by the end of the project.

A letter soliciting pilot participation was sent to the end user group members. A copy of the letter is shown in Appendix A. The initial pilot 
user group was composed of the following users:

George I. Ball

Philip D. Bantz

Brady V. Barnhart

William R. Feairheller

Nancy Guinta

Daniel R. Hill

Thomas W. Hughes
Thomas Z. Jones

Donald E. Sharp

Robert L. Stanley

R. Steven Tunning

Robert A. Welch

W. Doug Williams

David A. Zorich

Because of the development of the Project Accounting and Control System and the time sheet entry system for the Applied Computer and Systems Technology (AC\&ST) section, all personnel in AC\&ST were added as ORACLE subscribers. Although not officially members of the pilot study group, they provided valuable insights and observations on the various operations of the UCS.

\section{System Overview}

The system manager for the UCS was John Edelmann. The database administrator (DBA) was John Gondert. They were responsible for creating user accounts, managing disk space, and managing the ORACLE system on the UCS.

Any Mound employee who has a terminal or personal computer (PG) may subscribe to the UCS. The forms for requesting access may be found in the Information Center in OSW-136.

An introductory course on using ORACLE on the UCS is available. To get the maximum use out of the UCS, prospective subscribers are urged to take the course prior to using the ORACLE system. Persons interested in taking the introductory course should contact Lynn Taylor at extension 3899 or Nancy Howell at extension 3724.

Storage space for user-created tables will be made available to those individuals who need to create and share data on the UCS. Five Mbytes of on-line disk storage will be allocated to each user for table and program storage. 
Any UCS subscriber may request that specific unclassified data residing on the production computer system (PCS) be moved into ORACLE tables on the UCS. This request should be forwarded via the automated office support system (AOS) to the Information Center (INFOCNTR), or the requestor may contact the Information Center in OSW-136 (extension 3724). The request will be evaluated based on the number of users who would benefit, the complexity and difficulty of the transfer, and the availability of resources to accomplish the transfer.

Creating copies of publicly available tables is strongly discouraged. Persons who want only specific columns of data from an ORACLE table should create a VIEW of the desired table. A VIEW takes up no storage space and provides the same functionality as a limited portion copy of a table.

\section{Naming Conventions}

A plantwide naming data dictionary is available to all ORACLE users in the SQL*DESIGN DICTIONARY (SDD) product.

If a column refers to the health physics (HP) number of a manager and will store HP numbers, then the column should be named HPNO_MANAGER and not MANAGER_HPNO. Similarly, if the reference is to the cost center of the sponsor, the column name should be COST_CENTER_SPONSOR, not SPONSOR_COST_ CENTER. All table and column names may be up to 30 characters long. Descriptive names connected with an underscore ( $)$ ) should be used for both table and column names (e.g., DATE_ASSEMBLY_TESTED, FACTOR_TO_MAKE_ SCHEDULE_OK, DESCRIPTION_ACST_PROJECT, CHEMICAL_FORMULA_ORGANIC, VOLUME_OF_ PIT_STP, DATE_GAGE_IAST_CAIIBRATED).

An additional feature available in SDD and a convention that may be useful is to prefix all tables within an application with the same letters (e.g., PROCODE tables currently all start with PC...; TIPS tables could all start with TIPS...). Also, within a specific table it may be helpful to prefix all column names with the same letters. This makes joins easier because the primary keys and foreign keys have unique names in each table. 
The SDD should be used for all single table and multiple table applications that are placed on the UCS. As a minimum, all entities and attributes should be defined using SDDMENU.

\section{Applications}

In ORACLE terminology, an "application" consists of an SQL*FORMS file with a file type of .INP. The machine language run time-version version has a file type of .FRM. The .INP file is ASCII and provides the ability to move applications from one hardware architecture to another. A single ORACLE application may contain from one to $\mathrm{N}$ screens and in some instances may be the whole application as users think of it (e.g., PACS).

At this point there are over 720 ORACLE applications existing on the UCS and defined in the ORACLE active data dictionary table IAPAPP.

All the applications are cataloged by the ORACLE active data dictionary. Also, eṿery field definition and specification, every trigger definition (including its syntax), and the screen mapping for the layout for the form are stored in the active data dictionary. Thus, application design in ORACLE is an integral, active part of the overall relational process. All these tables are publicly available for selection and can be used for either stored query execution or ad hoc query selection. Maintenance in this environment should be much easier, assuming most applications are written in SQL*FORMS and individuals performing the maintenance are well-versed in SQL*PLUS and SQL*FORMS.

An ORACLE form is composed of blocks that may refer to ORACLE tables. Blocks may span one or more "pages" or screens. Currently, there are almost 400 blocks defined in the ORACLE active data dictionary table IAPBLK for various applications.

An ORACLE block comprises one or more enterable or displayable fields. Field specifications are stored in the ORACLE dictionary table IAPFLD. Currently, there are over 15,000 fields defined in table IAPFLD. 
An ORACLE field may have one or more "triggers" associated with it to control information or logic flow throughout the application and to perform various edits against the data entered into the fields. Trigger specifications are stored in the ORACLE dictionary tables IAPTRG and IAPTRIGGER. Presently, there are over 15,000 triggers defined in the active ORACLE data dictionary.

ORACLE fields within a block are mapped to specific screen coordinates. The coordinates, the page reference, and the assciciated text for the field are stored in the ORACLE dictionary table IAPMAP. There are over 13,000 entries in this table at the present time.

Column names and column specifications for the IAP tables are presented in Appendix B.

\section{Tables}

The pilot user tables, including the system tables, number over 570 at this time. The tables include larger databases that were uploaded from user PCs and data downloaded from the PCS. In addition, over 100 views were created and over 300 synonyms are available on the UCS. A complete listing of tables, views, and synonyms can be found in Appendix $C$.

\section{PCS Data on the UCS}

Procedures were developed to extract data from the PCS, verify the data are unclassified, obtain clearance to remove the data from the PCS, upload the data to the UCS, and run SQL*LOADER to move the data into ORACLE tables. These procedures are discussed in Systems Manual 212, PCS to UCS Data Transfer. The types of data stored on the UCS are discussed in the following sections.

\section{Purchasing Data}

Data from purchasing IMS segments were downloaded and moved to ORACLE tables PURIDESC, PURITEM, PURORDER, and PURRECVT on the UCS.

\section{TRAC Data}

Data from TRAC file 21 (lot quantities built, ordered, reworked, etc.), 
TRAC file 22 (operations performed on products), and TRAC file 23 (bills of materials) were moved to ORACLE tables XTRAC21, XTRAC22, and XTRAC23, respectively, on the UCS.

\section{Technical Manuals Data}

Data from a dBASE file on a PC containing over 4,700 rows of information on technical manuals were loaded into ORACLE table MANUALS on the UCS.

\section{Materials Compatibility Chemical Reactivity Data}

Data from a dBASE file on a PC containing over 9,200 rows of information on materials compatibility chemical reactivity tests were loaded into ORACLE table CRTDB on the UCS.

\section{Budget Data}

Data for budgeted cost and actual cost were taken from the PCS and stored into ORACLE table BUDGET on the UCS.

\section{Employee Data}

Data on employees were moved from the PCS and loaded into ORACLE table EMPLOYEE.

\section{PROCODE Data}

Table PCPRDMST - This table contains data on product code, product name, drawing prefix, drawing body, and originating agency.

Table PCBLDMST - This table contains data on product code and family; design agency; unit of measure; responsible engineers, managers, and planners; lot size; and various status dates.

Table PCSCHDOP - This table contains data on product ID, operations, setup parameters, process times, tear down parameters, etc.

Table PCWORKOP - This table contains data on operations.

Table PCBLDBOM - This table contains data on bill of materials. 
Tables SPACETBL, MGRTABLE, and CCTABLE - These tables contain data on building and room space allocations at Mound by cost center, department, and responsible manager; manager identification; and cost center identification, respectively.

Table VDTABLE - This table is structured after the Variables Data System on the PCS and contains test data.

Tables prefixed with BU - Tables BU_BID, BU_BID_SENIORITY, BU_BID_VIEW, BU_ EMP, and BU_JOB contain data for the Bargaining Unit Information System.

\section{Applications Development Tables}

MESH - A large number of tables exist that will support the Mound Environmental, Safety \& Health (MESH) System. These tables will not be available to the general UCS user community. The MESH System will reside on a separate processor after it is operational.

SDAS - The Secret Document Accountability System (SDAS) tables will not be available on the UCS. These tables will be moved to a classified processor after the software is implemented.

TIPS - A large number of Test, Inspection, and Production System (TIPS) tables are available on the UCS. However, they are developmental and will be moved to a system dedicated to supporting manufacturing.

\section{Software}

The ORACLE Relational Database Management System (RDBMS) software on the UCS is composed of the machine-specific kernel; the command language, SQL*PLUS; the user interface, EASY*SQL; the CASE tool, SDD; the distributed processing feature using DECnet, SQL*NET; the ASCII to ORACIE conversion program, SQL*LOADER; the report generator, SQL*REPORT; and the forms processing language, SQL*FORMS. 


\section{SQL*PLUS}

The ORACLE command language SQL*PLUS contains a full complement of operators to allow English language type constructs for selecting from, inserting into, indexing, updating, and altering ORACLE tables. Also, there are numerous non-SQL primitives for controlling output formats and for controlling terminal and work session characteristics.

For example, to find the employee who has telephone extension 4396:

SELECT EMPLOYE_NAME FROM EMPLOYEE WHERE PHONE_NUMBER='4396';

The result is:

EMPLOYE-NAME

EIMUTIS, EDWARD C

To find out how many employees are in cost center 294:

SELECT COUNT(*) FROM EMPLOYEE WHERE COST_CENTER='294';

The result is:

$\operatorname{CoUNT}(*)$

12

Similarly, to find out how many people are in each building at Mound:

SELECT BUILDING, COUNT(*) FROM EMPLOYEE GROUP BY BUILDING;

The result. is:

BUILD COUNT(*)

-

$101 \quad 2$

$108 \quad 2$

$2 \quad 8$

Etc.

To list the names and phone numbers of people who work in each building:

BREAK ON BUILDING SKIP 1;

ELECT BUILDING, PHONE_NUMBER,EMPLOYE_NAME

FROM EMPLOYEE

ORDER BY BUILDING,EMPLOYE_NAME; 
The result is:

BUILD PHON EMPLOYE_NAME

$$
\begin{array}{rl}
101 & 3400 \text { LUNSFORD, JOHN } \\
& 3400 \text { PECK, ALBERT EDWARD } \\
108 & 5558 \text { LEVELI, KATHERINE } \\
& 5558 \text { RILEY, WAYNE TERRELL } \\
2 & 4090 \text { BAILEY, ELAINE } \\
& 4306 \text { HART, ROBERT } \\
& 4437 \text { HAWLEY, EDWARD A }
\end{array}
$$

Etc.

\section{EASY*SQL}

EASY*SQI is designed for people who need an easy-to-use interface into the ORACLE system. This product features context-sensitive help screens and pop-up windows to provide additional aids in using the product. The main menu allows the selection of QUERY, to generate queries from ORACLE tables; REPORT, to generate formatted reports based on stored queries; EDIT, to change or enter data into ORACLE tables; CREATE, to create ORACLE tables; GRAPH, to graph query results (if the user has a graphics terminal or graphics emulation software); and EXTENDED, to create views, revise. table structures, update sets of rows in a table, or delete selected rows in a table.

\section{SQL*DESIGN DICTIONARY}

SDD is an active computerized dictionary system, built on top of an ORACLE relational database, which holds and actively manages all the information collected and derived during the development and production run of a business system. SDD consists of over 90 on-line applications screens, reports, and programs which maintain the SDD database and provide a combination of working documents and management information during each stage in the development.

The SQL $*$ DEVELOPMENT METHOD helps the analyst develop business applications that meet user needs. It provides a standard approach to any business requirement and is specifically designed to help multiuser, high-perfor- 
mance systems on SQL based RDBMSs. It may also be used to specify and design other systems. This method splits the development process into well-defined and manageable stages. These stages are illustrated in Figure 1.

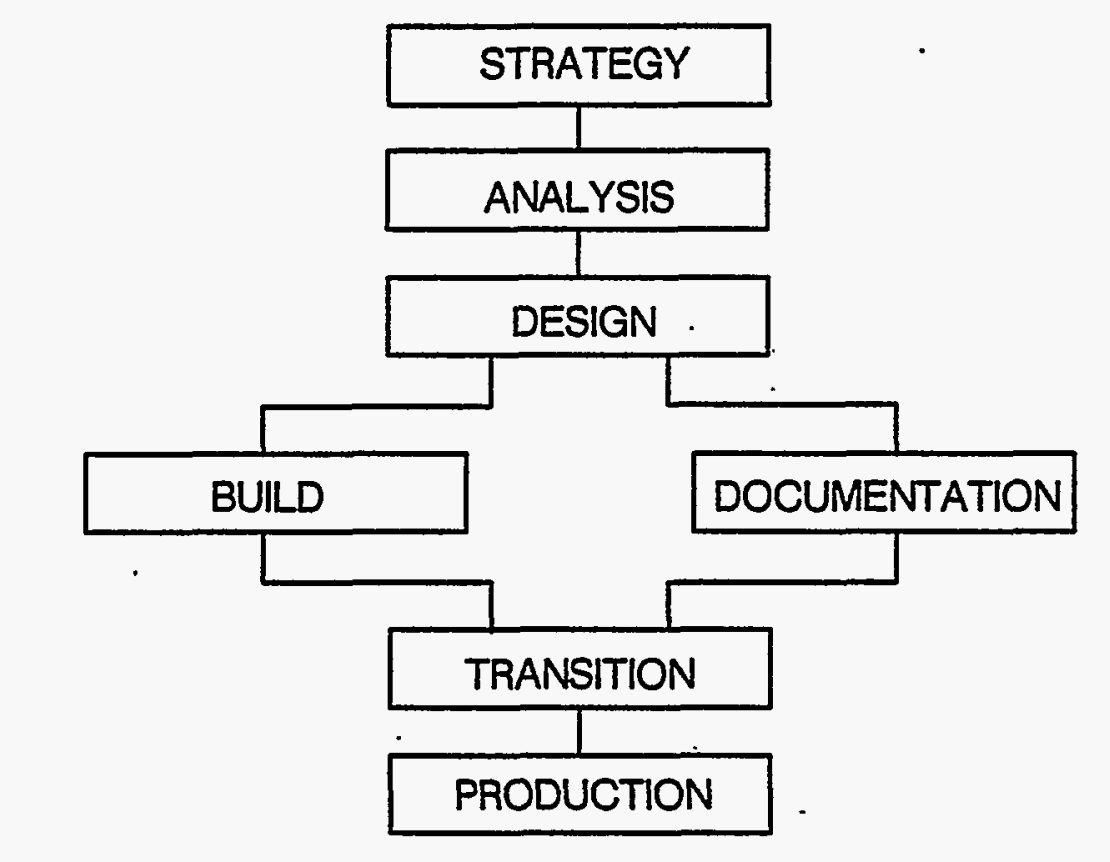

- Figure 1 - Stages of the SQI*DEVELOPMENT METHOD.

The stages in a system life cycle are listed below:

- Strategy - Determine what needs to be done and how much it should cost.

- Analysis - Specify the user requirements.

- Design - Decide what the system should look like and what tools and components should be used.

- Implementation

- Build - Develop the system.

- Documentation - Write the user guide.

- Transition - Implement actions for smooth conversion to the new system.

- Production - Implement the system and create an environment for ongoing maintenance and enhancements.

During the development of a system, a great deal of information needs to be collected and organized. A design dictionary is a tool for managing 
this information throughout the development process.

The SDD is a computerized database system that not only stores information, but also provides active support in the following areas:

- Determining system requirements and checking the completeness of their specifications.

- Designing the computer system and manual procedures to meet the requirements.

- Automating the system implementation.

- Creating system documentation.

SDD provides the mechanism to undertake continuous consistency and quality checks throughout the analysis and design process, then provides the option to generate relational database structures automatically. SQL statements to create tables, views, and indexes are generated directly from the application. See Appendix D for a sample SDD entity and attribute report.

\section{SQL *NET}

ORACLE allows the distributed processing of information stored in various nodes of a. DECnet system in a manner totally transparent to the user or application program. Having defined as a database link the location of a table, the user need only enter the synonym name in a selected statement to retrieve data from a remote location. For example, the following steps will allow distributed retrieval from table "nuts_and_bolts" on the remote database "database_test":

CREATE PUBLIC DATABASE LINK 1ink_ucs CONNECT TO system IDENTIFIED BY manager USING 'D:database_test';

CREATE PUBLIC SYNONYM tools

FOR nuts_and_bolts@link_UCS;

SELECT * FROM tools; 


\section{SQL*LOADER}

SQL*LOADER is a product for moving data in external files into tables in an ORACLE database. SQL*LOADER can perform the following functions:

- Load data from multiple data files of different types.

- Handle fixed format, delimited format, and variable length records.

- Support a wide range of data types, including DATE, BINARY, and PACKED DECIMAL.

- Load multiple tables during the same run, loading selected rows into each table.

- Combine multiple physical records into a single logical record.

- Treat a single physical record as multiple logical records.

- Generate unique, sequential key values in specified columns.

- Load data from disk or tape.

- Provide thorough error reporting capabilities so that records can be easily adjusted and reloaded.

\section{SQL*REPORT}

SQL*REPORT can be used to create ordinary letters or tabular reports. It can also be used to produce a report from a single ORACLE table, with column headings, columns of database information, and totals as desired. More complex documents SQL*REPORT can generate include reports with many levels of nesting, multiple breaks on columns, and a wide variety of subtotals and totals, as well as disjunctive reports. Although this product has powerful features, it is difficult to use and is not recommended for the general user environment.

\section{SQL*FORMS}

SQL*FORMS lets the users design custom forms appropriate for their information handling functions. These forms allow fast and easy data entry, updates, deletions, and queries to an ORACLE database. 
SQL*FORMS gives the user the ability to perform the following functions:

- Insert data into the database by typing the data directly into the correct fields.

- View, update, or delete several records on the screen simultaneously.

- Type query conditions directly into the fields the user wants to query.

In its more advanced uses, SQL*FORMS lets an application developer protect the database, display calculated data, and generate historical records. A wide variety of triggers can be used to maintain consistency among tables, to control and alter the sequence through a series of forms, and to validate data input.

\section{Hardware}

A Digital Equipment Corporation (DEC) VAX 8700 with 48 Mbytes of memory was selected as the UCS processor. The processor was clustered with the AOS cluster to provide a high-speed, highly available computing resource to the Mound user community.

\section{Additional Requirements}

\section{Training}

UCS USER TRAINING

Mound Training personnel have developed and are currently offering a course on using ORACLE in the UCS environment. The course is in its initial stages and no recommendations are available at this time. Once sufficient feedback has been collected, any necessary changes will be recommended.

\section{APPLICATION DEVELOPER TRAINING}

The ORACLE product set for application developers is complex. The number of trained ORACLE application developers needs to be increased. An in-house course for application developers should be made available.

The SDD is an important product for application development at Mound. In-house training on the benefits and uses of SDD needs to be made available to the application developers and other interested parties. 


\section{Software}

SQL*REPORT WRITER

The reporting features of the ORACLE product set currently on the UCS are deficient from an end-user perspective. Although the report option in EASY*SQL can handle simple report generation in a user-friendly fashion, purchasing and installing the SQL*REPORT WRITER on the UCS is recommended.

ORACLE TPS

Version 6.0 of the ORACLE product will have an optional Transaction Processing System (TPS) to speed up queries and other SQL operations. Based upon the size of the tables the users will be querying and the speed of some of the queries, the TPS enhancement will provide significant response time improvements. Purchasing the TPS option of the version 6.0 upgrade for the UCS is recommended.

\section{APPLICATION FOUNDATION}

Application Foundation iș an advanced tool set used for building. commercial-quality applications. It is fully integrated with the new version 3.0 of SQL*FORMS. Purchasing and installing the Application . Foundation tool set on the UCS is recommended.

ALL-IN-1 :

Access to predefined applications (e.g., PACS and TIMESHEETS) can be made available directly from menu choices on AOS. The DEC ALL-IN-1 product license should be purchased for the UCS.

SQL*A1

An interface between ORACLE and ALL-IN-1, SQL*A1, will allow users to store and retrieve ALI-IN-I documents in ORACLE and to retrieve ORACLE held data or text into ALL-IN-1 documents. Purchasing this product for the UCS is recommended.

\section{CASE TOOLS}

Computer-aided software engineering (CASE) is an emerging technology that provides automated support for software developers at all levels. The ORACLE CASE family consists of CASE*METHOD, CASE*DICTIONARY, and 
CASE*DESIGNER, ORACLE's new graphic interface to CASE*DICTIONARY. SDD should be upgraded to CASE*DICTIONARY, and CASE*NETHOD and CASE*DESIGNER should be purchased and installed on the UCS.

\section{Hardware}

DISK STORAGE

With the allocation of 5 Mbytes of disk space for each user, 200 subscribers (the number expected to be using the UCS by the end of CY 1988) will require 1 Gbyte of disk space. Production tables moved from the PCS are likely to take another 1 Gbyte of disk storage. Currently, 2.5 Gbytes exist for user table and system table storage. The new DEC SA-600 disk storage unit with 10 Gbytes of storage was procured in mid-1989.

\section{PROCESSORS}

The current VAX 8700 should be adequate in terms of simultaneous user support and response time well into 1989. However, this is based on published reports and not on experience at Mound. The 8700 should be upgraded sometime in FY 1990. Utilization and response time data should be used to determine whether the upgrade should be to a VAX 6000-410 or to a dyadic VAX 6000-420 processor.

\section{Database Administration}

The DBA for the UCS will need to develop procedures and standard programs for account maintenance and table maintenance. A conversion to version 6.0 will occur soon. An ORACLE hardware consultant should be brought in to help tune the system for TPS after the version 6.0 installation.

\section{Summary}

The UCS pilot project was successfully completed. The ORACLE RDBMS was installed and is fully operational on a DEC VAX 8700 . The VAX 8700 is dedicated to the Mound user community to meet its various computing needs. It is an unclassified, interactive processor that can accommodate 120 users simultaneously. Fourteen users initially participated in the pilot project, but by the end of the project there were over 150 subscribers. 
Over 100 tables are available for use by UCS subscribers. These tables contain purchasing data, TRAC data, employee data, budget and cost data, the Mound data dictionary, TIPS data, project status data, design dictionary entries, and several tutorial tables. Operational software and procedures were written and implemented to download data from the PCS and upload it into ORACLE tables on the UCS. An introductory course was developed and an initial user group has undergone training.

\section{Acknowledgments}

Dan Hill was the prime mover in finally obtaining a general purpose, unclassified, nonproduction computer for the exclusive interactive use of the Mound community. Dave Michaels and his Computer Operations staff also provided valuable assistance for this project. Also invaluable was the dedicated programming and training support of individuals in Ron D'Amico's group: Chris Brunson, Ron Bundy, and Nancy Howell. John Edelmann provided systems management services, and John Gondert provided not only the needed experience to make some nearly impossible tasks seem easy, but also the single-minded inspiration to keep us moving forward when all movement had ceased.

\section{Reference}

1. Eimutis, E. C., Mound End User Information-Handling Requirements, MLM-MU-87-61-0022, EG\&G Mound Applied Technologies (January 1987), 49 pp. 


\section{$c$}


Appendix A

Letter Soliciting Pilot Participation 
A large scale computer and integrated software tools are being acquired and will be dedicated to meet the general unclassified information handing needs of the Mound user community.

The User Computer system (UCS) will not run any batch jobs and will not be used for any "production" type of work. It will be an interactive, easy to use system, dedicated to meeting your unclassified information handling needs. Unclassified production, Cost center financial, Eso, purchasing and other data available on the Production Computer system (PCS) will be made available on the UCS.

We are looking for individuals to participate as members of a pilot group to implement the UCS. As a member of the pilot group you will be asked to spend about one man-week of effort over the next two months doing the following tasks.

* Identifying data that you need to access and retrieve.

* Learning to use the system.

* Using the system.

* Providing feedback on how adequately the system met your needs.

* Filling out a survey questionnaire.

* Suggesting other applications that would meet your information handing needs.

* Attending two meetings.

You should also meet the following criteria.

* You should be an Aos user.

* You should have a periodic need to access unclassified data on the mainframe (purchase order status, Eso status, and so on).

* You should not be an expert computer user. We want to evaluate the ease of use of the system by the infrequent computer user.

* You should have your supervisor's approval to participate. Even though your involvement will be less than a man-week of effort, your supervisor will need to agree on your participation.

If you satisfy these requirements and would like to participate in the pilot group, please reply to this memo via AOS indicating your interest.

Thank you.

Ed Eimutis

Senior Coordinator IV

Integrated Systems Management Group

P.S. Whether you are or are not interested in being a member of the pilot study group, would you take a moment and send a list to me of unclassified data that you need to access most frequently? Thank you. 


\section{Appendix B}

\section{Description of IAP Tables}


Table IAPTRG.

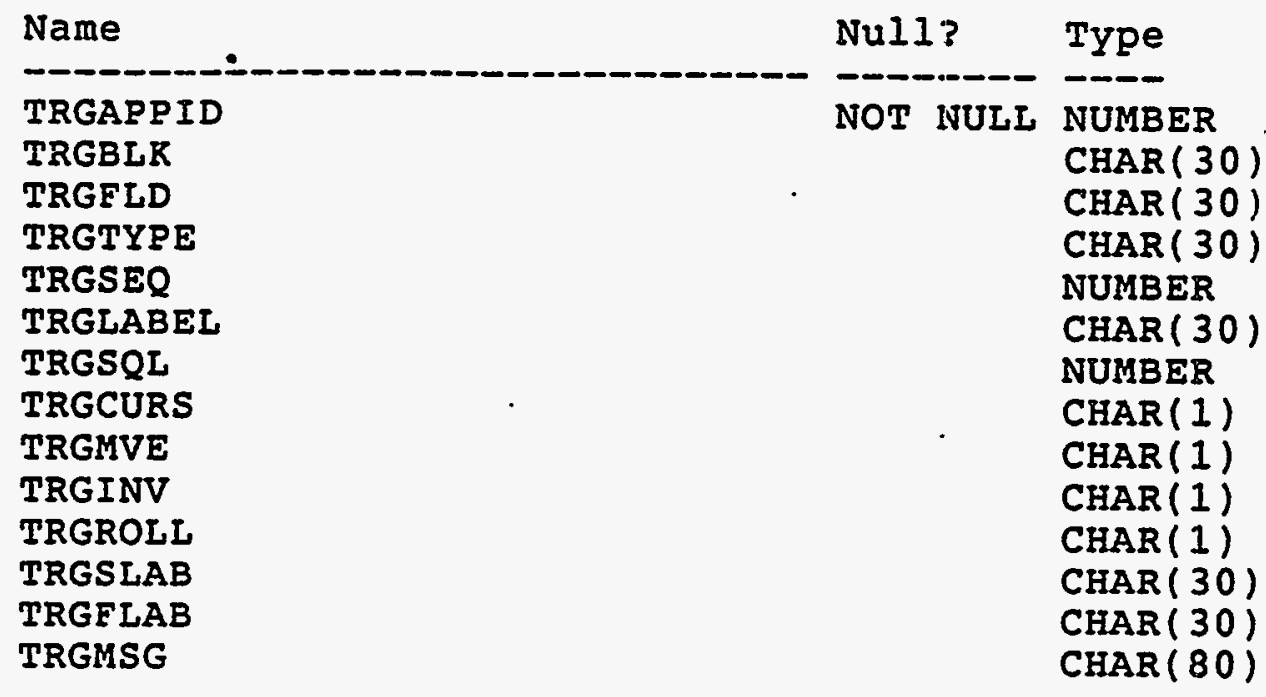

Table IAPTRIGGER.

\begin{tabular}{lll} 
Name & NUII' & TYPe \\
\hline TRIGAPPID & NOT NULL NUMBER \\
TRIGBLR & & $\operatorname{CHAR}(30)$ \\
TRIGEID & & $\operatorname{CHAR}(30)$ \\
TRIGTYPE & & \\
TRIGDESC & NOT NULL $\operatorname{CHAR}(30)$ \\
TRIGHIDE & & $\operatorname{CHAR}(20)$ \\
& & $\operatorname{CHAR}(1)$
\end{tabular}




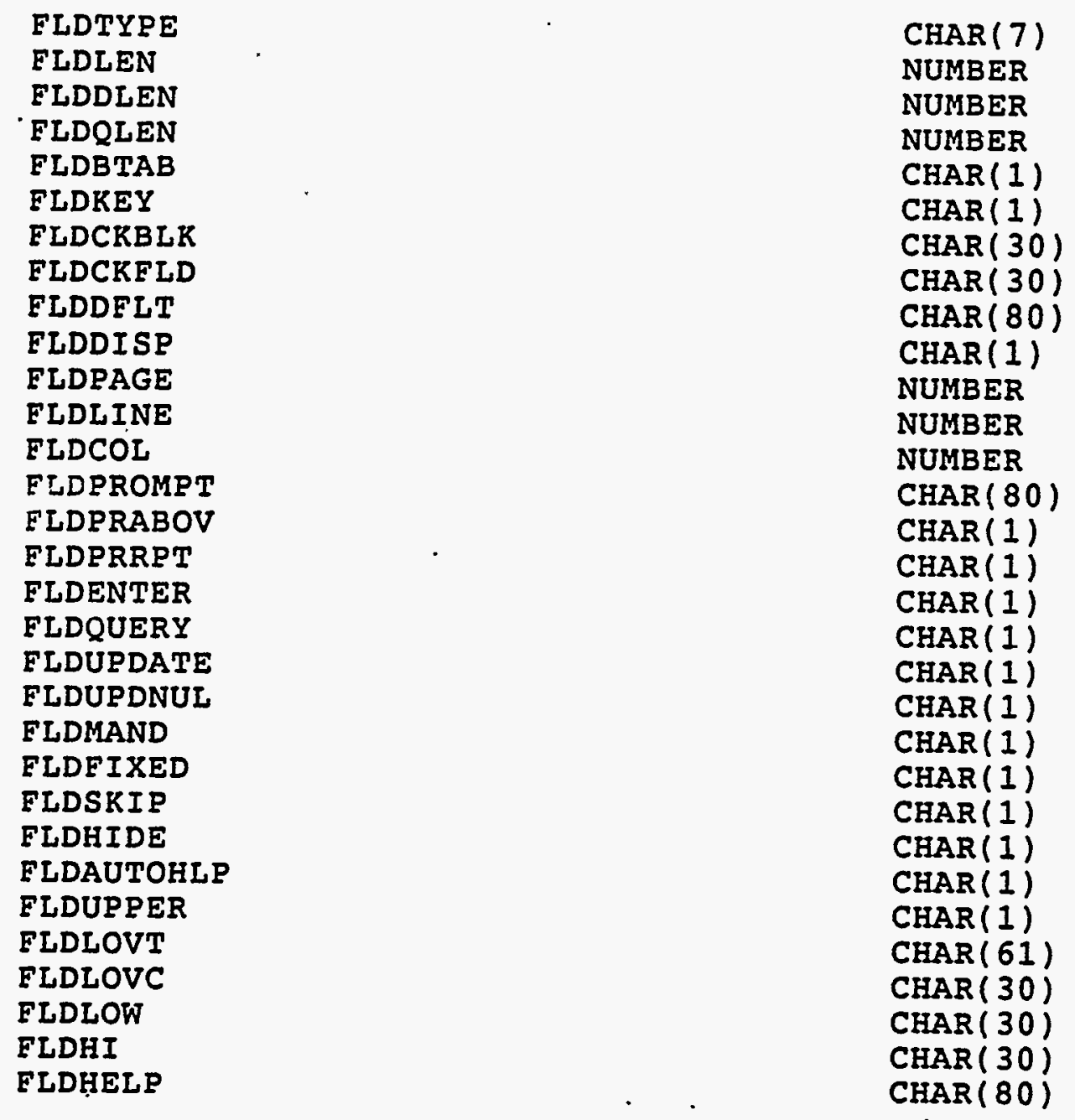

Table IAPMAP.

\begin{tabular}{lll} 
Name & Null? & TYPe \\
\hline MAPAPPID & NOT NULI NUMBER \\
MAPPAGE & NOT NULL NUMBER \\
MAPLINE & & NUMBER \\
MAPGRPH & CHAR(1) \\
MAPTEXT & & CHAR(132)
\end{tabular}

Table IAPSQLTXT.

\begin{tabular}{|c|c|c|}
\hline Name & Nul I? & Type \\
\hline $\begin{array}{l}\text { SQTAPPID } \\
\text { SQTNO } \\
\text { SQTLINE } \\
\text { SQTTEXT }\end{array}$ & $\begin{array}{l}\text { NOT NULL } \\
\text { NOT NULL }\end{array}$ & $\begin{array}{l}\text { NUMBER } \\
\text { NUMBER } \\
\text { NUMBER } \\
\text { CHAR }(80)\end{array}$ \\
\hline
\end{tabular}


Table IAPAPP.

\begin{tabular}{|c|c|c|}
\hline Name & Nu11? & Type \\
\hline $\begin{array}{l}\text { APPID } \\
\text { APPOWNER }\end{array}$ & $\begin{array}{l}\text { NOT NULL } \\
\operatorname{CHAR}(30)\end{array}$ & NUMBER \\
\hline APPNAME & NOT NULL & $\operatorname{CHAR}(30)$ \\
\hline APPTITLE & CHAR $(80)$ & \\
\hline APPWKSIZE & NUMBER & \\
\hline
\end{tabular}

Table IAPBLK.

Name
BLKAPPID
BLKNAME
BLKDESC
BLKHIDE
BLRSEQ
BLKUNQKEY
BLKCTRL
BLKTOWNER
BLKTNAME
BLKNOREC
BLKNOBUF
BLKBLIN
BLRLNRC
BLKOBYSQL

Null? Type

NOT NULL NUMBER

NOT NULL CHAR( 30$)$

CHAR (60)

CHAR (1)

NUMBER

CHAR (1)

CHAR (1)

$\operatorname{CHAR}(30)$

CHAR ( 30$)$

NUMBER

NUMBER

NUMBER

NUMBER

NUMBER

Table IAPCOMMENT.

Name
CMTAPPID
CMTBLK
CMTFLD
CMTTRGTYP
CMTTRGSEQ
CMTLINE
CMTTEXT

\begin{tabular}{ll} 
NUI1? & TYPe \\
\hline NOT NULL & NUMBER \\
& CHAR(30) \\
& CHAR(30) \\
& CHAR(30) \\
& NUMBER \\
& NUMBER \\
& CHAR( 80$)$
\end{tabular}

Table IAPFLD.

Name

FLDAPPID

FLDBLK

FLDNAME

FLDSEQ
NuIl? Type

NOT NULL NUMBER

NOT NULL CHAR(30)

NOT NULL CHAR(30)

NUMBER 
Appendix C

\section{ORACLE Tables, Views, and Synonyms}


-4 GONDJW

-13 GONDJW

-9 GONDJW

4481 GONDJW

5942 GONDJW

8096 GONDJW

5058 GONDJW

9736 GONDJW

6227 GONDJW

5321 GONDJW

-7 GONDJW

7976 GONDJW

16349 GONDJW

11586 GONDJW

15891 GONDJW

5178 GONDJW

15534 GONDJW

-14 GONDJW

2491 GONDJW

2536 GONDJW

15529 GONDJW

18711 GONDJW

19151 GONDJW

19351 GONDJW

19541 GONDJW

6681 GONDJW

-6 GONDJW

3206 GONDJW

-17 GONDJW

-17 GONDJW

-23 GONDJW

-12 GONDJW

-15 GONDJW

-16 GONDJW

-19 GONDJW

-14 GONDJW

-19 GONDJW

-10 GONDJW

-11 GONDJW

-14 GONDJW

-17 GONDJW

-2 GONDJW

-9 GONDJW

-16 GONDJW

-13 GONDJW

-17 GONDJW

-1 GONDJW

-20 GONDJW

-17 GONDJW

-9 GONDJW

-11 GONDJW

-12 GONDJW

-4 GONDJW

-14 GONDJW

-18 GONDJW

-24 GONDJW

-24 GONDJW

-2 GONDJW

-24 GONDJW

-8 GONDJW

-22 GONDJW

-2 GONDJW

-16 GONDJW
APPLICATION ENTITIES

APPLICATION FUNCTIONS

APPLICATIOIN_TABLES

BUDDEC

BUDFEB

BUDGET

BUDJAN

BUDMAR

BUDNOV

BUDOCT

CODE CONTROLS

DATAD̄ICT

DISKSPAC

DUMMY

EHPLOYE

EKPLOYEE

EMPMSUY

ENTITIES

EZCONTROI

EIELDDESC

MAILDATA

PURIDESC

PURITEM

PURORDER

PURRECVT

QMX INTERNAL DATA

REF VALUES

SDDENTITY

SDD APPLICATION DATASTORES

SDD APPIICATION MODULES

SDD APRIICATION SYSTEMS

SDD ARC ENTRIES-

SDD ATTRIRUTES

SDD ATTRIBUTE VALUES

SDD-CC ATTRIBUTTES

SDD CC COLUHNS

SDD- CHĀNGE HISTORY

SDD COLUMNS

SDD COLUMN ALIASES

SDD COMMON RELATIONSHIPS

SDD DATAFLOWS

SDD DATASTORES

SDD-DESCRIPTIONS

SDD DFLOW ATT USAGE

SDD DOMAIÑS

SDD-DOM COL ATTS

SDD DSTŌRE: ĀTT USAGE

SDD ENT TR $\bar{E} E$

SDD ERRŌRE

SDD EVENTS

SDD FILES

SDD EUNCTIONS

SDD FUNCTYON MODULE IMPL

SDD FUNC ATT $\bar{R}$ MATRIX

SDD INDE $\bar{X} F S$

SDD INDEX ENTRIES

SDD MENU

SDD MODULES

SDD MOD COL USAGE

SDD NOTES

SDD RELATIONSHIP ENDS

SDD-RELATION SELECTIONS

SDD_RELEASE_N̄OTES
SYNOHYH

SYNONYM

SYNONYM

VIEW

VIEW

TABLE

VIEW

VIEW

VIEW

VIEW

SYNONYM

TABLE

TABLE

TABLE

TABLE

TABLE

VIEW

SYNONYM

TABLE

TABLE

TABLE

TABLE

TABLE

TABLE

TABLE

TABLE

SYNONYM

TABLE

SYNONYM

SYNONYM

SYNONYM

SYNONYM

SYNONYM

SYNONYM

SYNONYM

SYNONYM

SYNONYM

SYNONYM

SYNONYM

SYNONYM

SYNONYM

SYNONYM

SYNONYM

SYNONYM

SYNONYM

SYNONYM

SYNONYM

SYNONYM

SYNONYM

SYNONYM

SYNONYM

SYNONYM

SYNONYM

SYNONYM

SYNONYM

SYNONYM

SYNONYM

SYNONYM

SYNONYM

SYNONYM

SYNONYM

SYNONYM

SYNONYM 


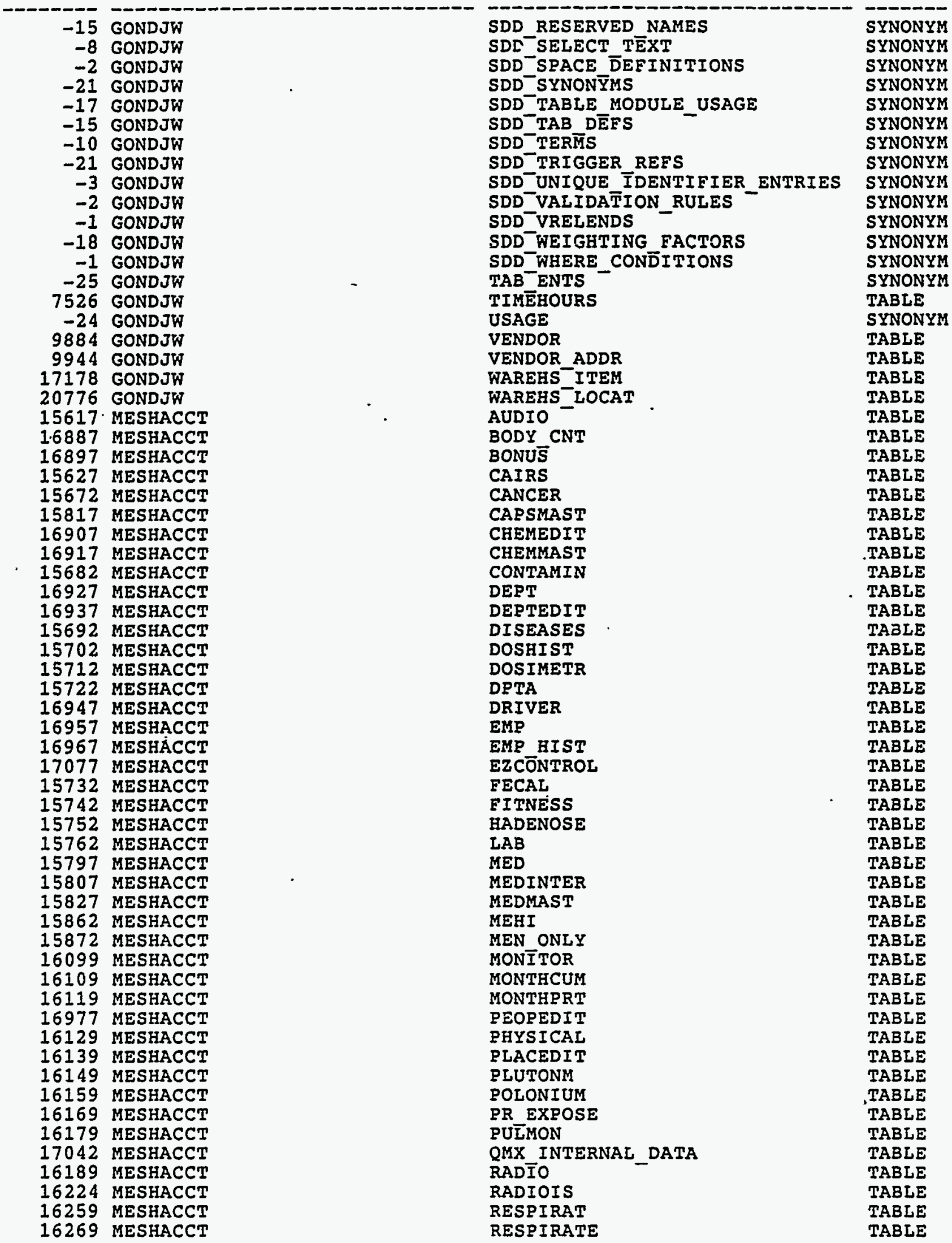


17032 MESHACCT

16279 MESHACCT

16289 MESHACCT

16299 MESHACCT

16309 MESHACCT

16319 MESHACCT

16329 MESHACCT

16339 MESHACCT

16987 MESHACCT

17022 MESHACCT

10357 OPS\$ASARVB

10337 OPS\$ASARVB

10295 OPS\$ASARVB

2081 OPS\$BALLGI

3746 OPS\$BALLGL

5311 OPS\$BALLGL

5301 OPS\$BALLGI

4484 OPS\$BALIGL

4487 OPS\$BALLGL

4490 OPS\$BALLGI

2066 OPS\$BALLGL

2072 OPS\$BALLGL

5449 OPS\$BALLGL

1210 OPS\$BARNBV

1245 OPS\$BARNBV

10367 OPS\$BERGZG

10317 OPS\$BERGZG

10304 OPS\$BERGZG

2226 OPS\$BROWCE

2236 OPS\$BROWCE

2246 OPS\$BROWCE

2256 OPS\$BROWCE

2266 OPS\$BROWCE

2286 OPS\$BROWCE

2276 OPS\$BROWCE

16241 OPS\$BRUNCD

22571 OPS\$BRUNCD

1275 OPS\$BRUNCD

22746 ORS\$BRUNCD

1740 OPS\$BRUNCD

22546 OPS\$BRUNCD

14386 OPS\$BRUNCD

15011 OPS\$BRUNCD

15286 OPS\$BRUNCD

14861 OPS\$BRUNCD

1455 OPS\$BRUNCD

635 OPS\$BRUNCD

16736 OPS\$BRUNCD

1625 OPS\$BRUNCD

7651 OPS\$BRUNCD

7626 OPS\$BRUNCD

10071 OPS\$BRUNCD

11461 OPS\$BUNDRD

3824 OPS\$BUNDRD

466 OPS\$BUNDRD

3832 OPS\$BUNDRD

2296 OPS\$BUNDRD

3116 OPS\$BUNDRD

2391 OPS $\$ B U N D R D$

10121 OPS\$BUNDRD

2771 OPS\$BUNDRD

5298 OPS\$BUNDRD

1580 OPS\$BUNDRD
SALGRADE

SAMPLING

SECURITY

TRAVEI

TRITIUM

TRITOXID

VISION

WEATHER

WIPE

WOMEN ONLY

EZCONT̄TOL

GRADE

PURCHASE

ADDRESS2

CRTDBGEO

EZCONTROL

GEORGE01

SPEARLIST

SPROI

SPKO2

TEST1

TEST2

TESTVIEW

BARTRACK

EZCONTROL

EZCONTROL

GRADE

PURCHASE

CLIENT

LINEITEMS

ORDERS

PRICELIST

PRODUCT

SEQNOS

STATUSCODE

CHEMINV

COST

EZCONTROL

MANAGER

OUTSTAND

PLAY

PURCHDESC

PURCEITEM

PURCHORDER

PURCHRECV

QMX INTERNAL DATA

TRAC 21

TRAC22

TRAC23

TRAC2 4

TRAC27

VARIANCE

BIDRPT

BLDGVIEW

BU BID

BU-BID SENIORITY

BU BID VIEW

$\mathrm{BU}^{-} \mathrm{EMP}$

$B U^{-}$JOB

CC产ABLE

DEPT

DEPTVIEW

DUMMY
TABLE

TABIE

TABLE

TABLE

TABLE

TABLE

TABLE

TABLE

TABLE

TABLE

TABLE

TABLE

VIEW

TABLE

VIEW

TABLE

TABLE

VIEW

VIEW

VIEW

VIEW

VIEW

VIEW

TABLE

TABLE

TABLE

TABLE

VIEW

TABLE

TABLE

TABLE

TABLE

TABLE

TABLE

TABLE

TABLE

TABLE

TABLE

TABLE

TABLE

TABLE

TABLE

TABLE

TABLE

TABLE

TABLE

TABLE

TABLE

TABLE

TABLE

TABLE

TABLE

TABLE

VIEW

TABLE

VIEW

VIEW

TABLE

TABLE

TABLE

TABLE

VIEW

TABLE 
TAB\$RBA OWNER

11451 OPS\$BUNDRD

10171 OPS\$BUNDRD

6996 OPS\$BUNDRD

10146 OPS\$BUNDRD

2362 OPS\$BUNDRD

6701 OPS\$BUNDRD

10096 OPS\$BUNDRD

3406 OPS\$COLELL

1866 OPS\$COLELL

-4 OPS\$COLELL

-13 OPS\$COLELI

-9 OPS\$COLELI

20601 OPS\$COLELL

1941 OPS $\$$ COLELL

20916 OPS\$COLELL

-7 OPS\$COLELL

21066 OPS\$COLELI

2466 OPS\$COLELL

9002 OPS\$COLELL

2016 OPS\$COLELL

3251 OPS\$COLELL

1916 OPS\$COLELL

9966 OPS\$COLELL

20966 OPS\$COLELL

22921 OPS\$COLELL

20526 OPS\$COLELL

20676 OPS\$COLELL

20651 OPS\$COLELL

22486 OPS\$COLELL

20626 OPS\$COLELL

20991 OPS\$COLELL

3381 OPS\$COLELL

22461 OPS\$COLELL

-22 OPS\$COLELL

-14 OPS $\$$ COLELL

10347 OPS\$COLELL

10327 OPSSCOLELL

20941 OPS\$COLELL

10301 OPS\$COLELL

1978 OPS\$COLELI

-14 OPS\$COLELL

-6 OPS\$COLELL

1791 OPS\$COLELI

-17 OPS\$COLELL

-17 OPS $\$$ COLELL

-23 OPS\$COLELL

-12 OPS\$COLELI

-15 OPS\$COLELL

- 16 OPS\$COLELL

-19 OPS\$COLELL

- 14 OPS\$COLELL

-19 OPS\$COLELL

-10 OPS\$COLELL

-11 OPS\$COLELL

-14 OPS\$COLELL

-17 OPS\$COLELL

-2 OPS\$COLELL

-9 OPS\$COLELL

-16 OPS\$COLELL

-13 OPS\$COLELL

-17 OPS\$COLELL

-1 ORS\$COLELL

-20 OPS $\$ C O L E L L$
TAB\$NAME

TABSTYP

EMPRPT

TABLE

TABLE

VIEW

TABLE

VIEW

TABLE

TABLE

TABLE

TABLE

SYNONYM

SYNONYM

SYNONYM

TABLE

TABLE

TABLE

SYNONYM

TABLE

TABLE

VIEW

TABLE

TABLE

TABLE

TABLE

TABLE

TABLE

TABLE

TABLE

TABLE

TABLE

TABLE

TABLE

TABLE

TABLE

SYNONYM

SYNONYM

TABLE

TABLE

TABLE

VIEW

TABLE

SYNONYM

SYNONYM

TABLE

SYNONYM

SYNONYM

SYNONYM

SYNONYM

SYNONYM

SYNONYM

SYNONYM

SYNONYM

SYNONYM

SYNONYM

SYNONYM

SYNONYM

SYNONYM

SYNONYM

SYNONYM

SYNONYM

SYNONYM

SYNONYM

SYNONYM

SYNONYM 
-17 OPS\$COLELL

-9 OPS\$COLELL

-11 OPS\$COLELL

-12 OPS\$COLELL

-4 OPS\$COLELI

-14 OPS\$COLELL

-18 OPS\$COLELL

-24 OPS $\$$ COLELL

-24 OPS\$COLELL

-2 OPS\$COLELL

-24 OPS\$COLELL

-8 ORS\$COLELL

-22 OPS\$COLELL

-2 OPS\$COLEIL

-16 OPS\$COLELL

-15 OPS\$COLELL

-8 OPS\$COLELL

-2 OPS\$COLELL

-21 OPS\$COLELL

-17 OPS\$COLELL

-15 OPS\$COLELL

- 10 OPS\$COLELL

-21 OPS\$COLELL

-3 OPS\$COLELL

-2 OPS\$COLELL

- 1 OPS\$COLELL

-18 OPS\$COLELL

-1 OPS\$COLELL

-25 OPS\$COLELL

-24 OPS\$COLELL

3481 OPS\$COLELL

3456 OPS\$COLELL

1 OPSSEIMUEC

10646 OPS\$EIMUEC

2069 OPS\$EIMUEC

16096 OPS\$EIMUEC

13143 OPS\$EIMUEEC

13153 OPS\$EIMUEC

13252 OPS\$EIMUEC

4261 OPS\$EIMUEC

13272 OPS\$EIMUEC

501 OPS\$EIMUEC

-12 OPS\$EIMUEC

1380 OPS\$EIMUEC

20451 OPS\$EIMUEC

-6 OPS\$EIMUEC

-25 OPS\$EIMUEC

-17 ORS\$EIMUEC

-3 OPS\$EIMUEC

-21 OPS\$EIMUEC

-16 ORS\$EIMUEC

-24 OPS\$EIMUEC

13292 OPS\$EIMUEC

2061 OPS\$EIMUEC

-15 OPS\$EIMUEC

-9 OPS\$EIMUEC

13302 OPS\$EIMUEC

2546 OPS\$EIMUEC

1988 OPS\$EIMUEC

5061 OPS\$ EIMUEC

3556 OPS\$EIMUEC

-21 OPS\$EIMUEC

10046 OPS\$EIMUEC
SDD ERRORS

SDD EVENTS

SDD FILES

SDD FUNCTIONS

SDD FUNCTION MODULE IMPL

SDD FUNC ATT $\bar{R}$ MATRI $\bar{X}$

SDD INDEX $\bar{X}$

SDD INDEX ENTRIES

SDD HENU

SDD MODULES

SDD MOD COL USAGE

SDD NOTES

SDD-RELATIONSHIP ENDS

SDD RELATION SELECTIONS

SDD RELEAS: N̄OTES

SDD RESERVED NAMES

SDD-SELECT TEXT

SDD-SPACE $\bar{D} E F I N I T I O N S$

SDD- SYNONYYMS

SDD TABLE MODULE_USAGE

SDD TAB DEFS

SDD TERTYS

SDD TRIGGER REFS

SDD UNIQUE IDENTIFIER ENTRIES

SDD_VALIDATION_RULES

SDD VRELENDS

SDD WEIGHTING FACTORS

SDD WHERE CONDITIONS

TAB ENTS

USA $\bar{E} E$

WORKEILE

WORKEILE2

ADMATDEV

AOSMESSGS

AOS SURVEY

APPĒUNC

APPLICATION ENTITIES

APPLICATION FUNCTIONS

APPLICATION TABLES

BONUS

CODE CONTROLS

CRTD $\bar{B}$

DD

DEPT

DOCDB

DOC ABSTRACT

DOC-CROSSREF

DOC CUSTODIAN

DOC INVENTORY

DOC TITLE

DOC TRANTYPE

DRĀ̄T STATUS

DUMMY

EMP

EMPLOYE

EMPLOYEE

ENTITIES

EPPLEY

EZCONTROL

HUGHES

MANUALS

MONTH TABLE

NEWINV
SYNONYM

SYNONYM

SYNONYM

SYNONYM

SYNONYM

SYNONYM

SYNONYM

SYNONYM

SYNONYM

SYNONYM

SYNONYM

SYNONYM

SYNONYM

SYNONYM

SYNONYM

SYNONYM

SYNONYM

SYNONYM

SYNONYM

SYNONYM

SYNONYM

SYNONYM

SYNONYM

SYNONYM

SYNONYM

SYNONYM

SYNONYM

SYNONYM

SYNONYM

SYNONYM

TABLE

TABLE

TABLE

TABLE

VIEW

VIEW

TABLE

PABLE

TABLE

TABLE

TABLE

TABLE

SYNONYY

TABLE

TABLE

SYNONYM

SYNONYM

SYNONYM

SYNONYM

SYNONYM

SYNONYM

SYNONYM

TABLE

TABLE

SYNONYM

SYNONYM

TABLE

TABLE

TABLE

TABLE

TABLE

SYNONYM

TABLE 
1470 OPS\$EIMUEC

21551 OPS\$EIMUEC

21526 OPS\$EIMUEC

7776 OPS\$EIMUEC

1940 OPS\$EIMUEC

10671 OPS\$EIMUEC

4006 OPS\$EIMUEC

-4 OPS\$EIMUEC

5288 ORS\$EIMUEC

13332 OPS\$EIMUEC

9916 OPS\$EIMUEC

6861 OPS\$EIMUEC

7726 OPS\$EIMUEC

7776 OPS\$EIMUEC

13242 OPS\$EIMUEC

13262 OPS\$EIMUEC

13377 OPS\$EIMUEC

13387 OPS\$EIMUEC

13397 OPS\$EIMUEC

13617 OPS\$EIMUEC

7806 OPS\$EIMUEC

13407 OPS\$EIMUEC

7736 OPS\$EIMUEC

13702 OPS\$EIMUEC

13637 OPS\$EIMUEC

13692 OPS\$EIMUEC

13282 OPS\$EIMUEC

13647 OPS\$EIMUEC

13417 OPS\$EIMUEC

13427 OPS\$EIMUEC

7716 OPS\$EIMUEC

13437 OPS\$EIMUEC

13447 OPS\$EIMUEC

13457 OPS\$EIMUEC

7796 OPS\$EIMUEC

13312 OPS\$EIMUEC

13467 OPS\$EIHUEC

13657 OPS\$EIMUEC

13477 OPS\$EIMUEC

13487 OPS\$EIMUEC

7826 OPS\$EIMUEC

13497 OPS\$EIMUEC

7786 OPS\$EIMUEC

13322 OPS\$EIMUEC

13367 OPS\$EIMUEC

7756 OPS\$EIMUEC

7816 OPS\$EIMUEC

7766 OPS\$EIMUEC

10.124 OPS\$EIMUEC

7746 OPS\$EIMUEC

13607 OPS\$EIMUEC

13567 OPS\$EIMUEC

13507 OPS\$EIMUEC

13577 OPS\$EIMUEC

13627 OPS\$EIMUEC

13517 OPS\$EIMUEC

13527 OPS\$EIMUEC

13537 OPS\$EIMUEC

13158 OPS\$EIMUEC

13547 OPS\$EIMUEC

13557 OPS\$EIMUEC

2901 OPS\$EIMUEC

17112 OPS\$EIMUEC
NEWVIEW

NEW T

OLD $T$

OPER̃ATIONS

PILOT

PROCUTIL

PROJEX

PUR ITEHS

QMX INTERNAL_DATA

REF VALUES

SCRIDDS

SDD ALT KEY ENTRIES

SDD-APPËICATTION DATASTORES

SDD APPLICATION MODULES

SDD APPIICATION SYSTEMS

SDD ARC ENTRIES

SDD-ATTR̄IBUTES

SDD ATTRIBUTE VALUES

SDD-CC ATTRIBUTTES

SDD CC- COLUMNS

SDD-CHĀNGE HISTORY

SDD-COLUMNS

SDD COLUMN ALIASES

SDD-COMMON RELATIONSHIPS

SDD-DATAFLOWS

SDD DATASTORES

SDD-DESCRIPTIONS

SDD DFLOW ATT USAGE

SDD-DOMAIÑS

SDDDOM COL ATTS

SDD_DSTŌRE ATTT_USAGE

SDD ENT TREE

SDD ERRŌRS

SDD EVENTS

SDD EILES

SDD-FUNCTIONS

SDD FUNCTION MODULE IMPL

SDD_FUNC ATT $\bar{R}$ KATRI $\bar{X}$

SDD INDE $\bar{X} E S$

SDD INDEX ENTRIES

SDD MENU

SDD MODULES

SDD MOD COL USAGE

SDD-NOTĒS

SDD RELATIONSHIP ENDS

SDD RELATION SELECTIONS

SDD RELEASE ÑOTES

SDD RESERVED NAMES

SDD ROW IDENTIEIERS

SDD SELECT TEXT

SDD SPACE DEEINITIONS

SDD SYNONYMM

SDD TABLE MODULE USAGE

SDD TAB DĒES

SDD TERTMS

SDD TRIGGER REES

SDD UNIQUE IDENTIFIER ENTRIES

SDD VALIDATION RULES

SDD VRELENDS

SDD WEIGHTING FACTORS

SDD WHERE CONDITIONS

SURV̄EY

TABLES
VIEW

TABLE

TABLE

TABLE

VIEW

TABLE

TABLE

SYNONYM

TABLE

TABLE

TABLE

TABLE

TABLE

TABLE

TABLE

TABLE

TABLE

TABLE

TABLE

TABLE

TABLE

TABLE

TABLE

VIEW

TABLE

TABLE

TABLE

TABLE

TABLE

TABLE

TABLE

TABLE

TABLE

TABLE

TABLE

TABLE

TABLE

TABLE

TABLE

TABLE

TABLE

TABLE

TABLE

TABLE

TABLE

TABLE

TABLE

TABLE

TABLE

TABLE

TABLE

TABLE

TABLE

TABLE

TABLE

TABLE

TABLE

TABLE

VIEW

TABLE

TABLE

TABLE

VIEW 
20426 OPS\$EIMUEC 326 OPS\$EIMUEC

7751 OPS\$EIMUEC

396 OPS\$EIMUEC

9941 ORS\$EIMUEC

10844 OPS\$EIMUEC

13597 OPS\$EIMUEC

-15 OPS\$EIMUEC

4206 OPS\$EIMUEC

7601 OPS\$EIMUEC

526 OPS\$EIMUEC

1611 OPS\$EIHUEC

15906 OPS\$EPPLRE

10374 OPS\$EPPLRE

15896 OPS\$EPPLRE

13756 OPS\$EPPLRE

6871 OPS\$EPPLRE

15916 OPS\$EPPLRE

5945 OPS\$EPPLRE

10384 OPS\$EPPLRE

5168 OPS\$EPPLRE

7201 OPS\$EPPLRE

13766 OPS\$EPPLRE

9731 OPS\$EPPLRE

10394 OPS\$EPPLRE

7211 OPS\$EPPLRE

15886 OPS\$EPPLRE

7231 OPS\$EPPLRE

7221 OPS\$EPPLRE

-2 OPS\$HOWENC

1968 OPS\$HOWENC

1590 OPS\$HOWENC

2786 OPS\$HOWENC

8861 OPS\$HOWENC

7196 OPS\$EOWENC

14181 OPS\$HOWENC

10766 OPS\$HUNGSA

21331 OPS\$HUNGSA

8876 OPS\$HUNGSA

1741 OPS\$HUNGSA

10956 OPS\$HUNGSA

2526 OPS\$HUNGSA

20801 OPS\$HUNGSA

9006 OPS\$HUNGSA

2056 OPS\$HUNGSA

3981 OPS\$HUNGSA

3956 OPS\$HUNGSA

15711 OPS\$HUNGSA

9026 OPS\$HUNGSA

15736 OPS\$HUNGSA

7051. OPS\$HUNGSA

7054 OPS\$HUNGSA

7095 OPS\$HUNGSA

10806 OPS\$HUNGSA

10746 OPS\$HUNGSA

10831 OPS\$HUNGSA

10881 OPS\$HUNGSA

8886 OPS\$HUNGSA

8826 OPS\$HUNGSA

TAB ENTS

TEM $\bar{P}$ COUNT

TEMP ROW

TEMP TTI

TEST

TIMESHEET

TIPS

TIPSX

TXX

UNIWRR

USAGE

VDTABLE

XPCPRDHST

XTRAC21

XTRAC22

XTRAC23

CLIENT

CUSTMAST

CUSTOMERS

DATES

EZCONTROL

LINEITEKS

LINE ITEMS

ORDER̄S

ORDLOG

PRICELIST

PRICES

PRODCAT

PRODITEMS

PRODUCT

SALES

SEQNOS

STATUSCODE

EMP

EZCONTROL

NANCY

NEW

PHONE

TEST2

TESTDATA

CC OTHER DISPS

CC REJECTS

COR̄MTBL

COST CENTERS

CUSTOMERS

DATA TYPES

DISP CODES

EXT M̄ANF ?ROD

FIEID ID SPECS

GEISHĀ FIELD IDS

GEISHA_TEST_CODES

GROUPS

INSPECTIOIN CODES

ITEM INFO

LEVETI ROA

LEVEL 2 ROA

LEVEL 3 ROA

LOTS

MEASUREMEINTS

OPERATIONS

OPERATORS

OPERTBL

OPNMTBL
TABLE

VIEW

VIEW

VIEW

TABLE

TABLE

TABLE

TABLE

TABLE

TABLE

TABLE

SYNONYM

TABLE

TABLE

TABLE

TABLE

TABLE

TABLE

TABLE

TABLE

TABLE

TABLE

TABLE

TABLE

TABLE

TABLE

TABLE

TABLE

TABLE

TABLE

TABLE

TABLE

TABLE

SYNONYM

TABLE

TABLE

TABLE

TABLE

TABLE

TABLE

TABLE

TABLE

TABLE

TABLE

TABLE

TABLE

TABLE

TABLE

TABLE

TABLE

TABLE

TABLE

TABLE

TABLE

VIEW

VIEW

VIEW

TABLE

TABLE

TABLE

TABLE

TABLE

TABLE 
PRODUCTS

TABLE

QC NUMBERS

TABLE

RAY

21141 OPS\$HUNGSA

REJECTS

REJECT CODES

15761 OPS\$HUNGSA

REJECT OTHER

REQUESTTORS

10931 OPS\$HUNGSA

1761 OPS\$HUNGSA

21041 OPS\$HUNGSA

7041 OPS\$HUNGSA

21406 OPS\$HUNGSA

20701 OPS\$HUNGSA

9686 OPS\$HUNGSA

10856 OPS\$HUNGSA

3531 OPS\$HUNGSA

3506 OPS\$HUNGSA

10981 OPS\$HUNGSA

11006 OPS\$HUNGSA

9696 OPS\$HUNGSA

3827 ORS\$HUNGSA

7098 OPS\$HUNGSA

1460 OPS\$JONESK

-20 OPS\$JONESK

3076 OPS\$LANGJA

3096 OPS\$LANGJA

5253 OPS\$LANGJA

3181 OPS\$LANGJA.

21246 OPS\$LANGJA

3931 OPS\$LANGJA

16141 OPS\$LANGJA

6936 OPS\$LANGJA

19911 OPS\$LANGJA

2696 OPS\$LANGJA

1900 OPS\$LANGJA

22671 OPS\$LANGJA

2791 OPS\$LANGJA

2541 OPS\$LANGJA

19861 OPS\$LANGJA

20401 OPS\$LANGJA

4558 OPS\$LANGJA

5283 OPS\$LANGJA

2666 OPS\$LANGJA

6981 OPS\$LANGJA

2766 OPS\$LANGJA

20211 OPS\$LANGJA

2441 OPS\$LANGJA

21091 OPS\$LANGJA

19961 OPS\$LANGJA

21221 OPS\$LANGJA

22696 OPS\$LANGJA

2926 OPS\$LANGJA

22646 OPS\$LANGJA

2146 OPS\$LANGJA

3051 OPS\$LANGJA

3001 OPS\$LANGJA

18686 OPS\$LANGJA

REWORKS

REWORK_CODES

ROA

SOURCE CODES

SPTABI $\bar{E}$

STATTBL

SUB LOTS

TEST CODE SPECS

TEST SPEC

TIPS

TIPS TEMP

TRAVTBL

VDTABLE

VIEW ROA

EZCONTTROL

SURVEY

AUDIO

BODY CNT

BONUS

CAIRS

CANCER

CAPSMAST

CHEMEDIT

CHEMMAST

CONTAMIN

DEPT

DEPTEDIT

DISEASES

DOSHIST

DOSIMETR

DPTA

DRIVER

DUMMY

EMP

EMP HIST

EZCŌNTROL

EECAL

FITNESS

HADENOSE

LAB

MED

MEDINTER.

MEDMAST

MEHI

MEN ONLY

MONITTOR

HONTHCUM

MONTHPRT

PEOPEDIT

PHYSICAL

PLACEDIT

PLUTONM

POLONIUM

PR EXPOSE

PUIMMN

TABLE

TABLE

TABLE

TABLE

TABLE

TABLE

TABLE

TABLE

TABLE

TABLE

TABLE

TABLE

TABLE

TABLE

TABLE

TABLE

TABLE

TABLE

VIEW

TABLE

SYNONYM

TABLE

TABLE

TABLE

TABLE

TABLE

TABLE

TABLE

TABLE

TABLE

TABLE

TABLE

TABLE

TABLE

TABLE

TABLE

TABLE

TABLE

TABLE

TABLE

TABLE

TABLE

TABLE

TABLE

TABLE

TABLE

TABLE

TABLE

TABLE

TABLE

TABLE

TABLE

TABLE

TABLE

TABLE

TABLE

TABLE

TABLE

TABLE

TABLE 
6971 OPS\$LANGJA

21116 OPS\$LANGJA

19886 OPS\$LANGJA

2876 OPS\$LANGJA

19986 OPS\$LANGJA

4548 OPS\$IANGJA

2976 OPS\$LANGJA

20476 OPS

2741 OPS\$LANGJA

2591 OPS\$LANGJA

2951 OPS\$LANGJA

20501 OPS\$LANGJA

3026 OPS\$LANGJA

276 OPS\$IANGJA

22621 OPS\$LANGJA

2562 OPS\$MAXFAD

11320 OPS\$MAXFAD

11310 OPSSMAXFAD

6082 OPS\$MAXFAD

101.94 OPS\$MAXFAD

7873 OPS\$MAXFAD

8992 OPS\$MAXFAD

10204 OPS\$MAXFAD

5243 OPS\$MAXFAD

9744 OPS\$MAXFAD

1420 OPS\$MIIIGD

5452 OPS\$MILIGD

7581 OPS\$MUSEDI

10249 OPS\$MUSEDL

17140 OPS\$OCONMJ

1635 OPS\$QUIIL

6230 OPS\$QUILI

6250 OPS\$QUIII

3726 OPS\$REEDRD

3736 OPS\$REEDRD

10298 OPS\$SHEPDJ

10434 OPS\$SPENMA

1030.7 OPS\$SPENMA

10289 OPS\$SPENMA

10292 OPS\$STANMJ

2797 OPS\$ZORIDA

6240 OPS\$ZORIDA

10834 PRODUCTION

2309 PRODUCTION

15526 PRODUCTION

11169 PRODUCTION

7861 PRODUCTION

1355 PRODUCTION

1365 PRODUCTION

7026 PRODUCTION

7036 PRODUCTION

10624 PRODUCTION

8986 PRODUCTION

8901 PRODUCTION

-11 PUBIIC

-8 PUBLIC

-4 PUBIIC

-13 PUBLIC

-9 PUBLIC

-5 PUBLIC

-25 PUBLIC

-18 PUBLIC

-20 PUBLIC
QMX INTERNAL DATA

RADIO

RADIOIS

RESPIRAT

RESPIRATE

SALGRADE

SAMPIING

SECURITY

TRAVEL

TRITIUM

TRITOXID

VISION

WEATBER

WIPE

WOMEN ONLY

ANN

BONUS

DEPT

DUMMY

DUNN

EMP

EZCONTROL

MAX

PURCHASE

SALGRADE

EZCONTROL

ROSTER

EZCONTROL

VAULTS

DEPT1

CENACC

OP0935FX

OR1075FX

BILLY

EZCONTROL

PURCHASE

EZCONTROI

GRADE

PURCHASE

PURCHASE

EMPLOYEE79

PHONE

BU BID

BU-BID SENIORITY

BU BID VIEW

BU EMP

$B U^{-} J O B$

PC $\bar{B} L D B O M$

PCBLDMST

PCPRDMST

PCSCHDOP

PCWORKOP

PROJECT

SEQNOS

ACCESS AUTH

ADMATDEV

APPLICATION ENTITIES

APPLICATION FUNCTIONS

APPLICATION TABLES

AUDIT ACCESS

AUDIT-ACTIONS

AUDIT CONNECT

AUDITDBA
TABLE

TABLE

TABLE

TABLE

TABLE

TABLE

TABLE

TABLE

TABLE

TABLE

TABLE

TABLE

TABLE

TABLE

TABLE

VIEW

TABLE

TABLE

TABIE

TABIE

TABLE

TABLE

TABLE

VIEW

TABLE

TABLE

TABLE

TABLE

TABLE

TABLE

TABLE

TABLE

TABLE

TABLE

TABLE

VIEW

TABLE

TABLE

VIEW

VIEW

VIEW

VIEW

TABLE

VIEW

VIEW

TABLE

TABLE

TABLE

TABLE

TABLE

TABLE

TABLE

TABLE

TABLE

SYNONYM

SYNONYM

SYNONYM

SYNONYM

SYNONYM

SYNONYM

SYNONYM

SYNONYM

SYNONYM 
-1 PUBLIC

-1 PUBLIC

-1 PUBLIC

-12 PUBLIC

-22 PUBLIC

-19 PUBLIC

-4 PUBLIC

-9 PUBLIC

-14 PUBLIC

-23 PUBLIC

-16 PUBLIC

-8 PUBLIC

-20 PUBLIC

-25 PUBLIC

-5 PUBLIC

-17 PUBLIC

-5 PUBLIC

-7 PUBIIC

-23 PUBLIC

-21 PUBLIC

$\because 8$ PUBLIC

-8 PUBLIC

-18 PUBLIC

-17 PUBLIC

-25 PUBLIC

-7 PUBLIC

-13 PUBLIC

-2 PUBLIC

-7 PUBLIC

-9 PUBLIC

-6 PUBLIC

-25 PUBLIC

-17 PUBLIC

- 3 PUBLIC

-14 PUBLIC

-19 PUBLIC

-21 PUBIIC

-16 PUBLIC

-24 PUBLIC

-9 PUBLIC

-20 PUBLIC

-22 PUBLIC

-2 PUBLIC

-15 PUBLIC

-9 PUBLIC

-14 PUBLIC

-6 PUBLIC

-18 PUBLIC

-8 PUBLIC

-19 PUBLIC

-11 PUBIIC

-25 PUBLIC

-8 PUBLIC

-16 PUBLIC

-15 PUBLIC

-6 PUBLIC

-1 PUBLIC

-4 PUBLIC

-24 PUBLIC

-5 PUBLIC

-25 PUBLIC

-8 PUBLIC

-2 PUBLIC
AUDIT EXISTS

AUDIT TRAIL

AUTHOR̄S

BIGEMP

BORDER

BUDGET

BU BID

BU BID SENIORITY

BU BID-VIEW

BU EMP

$\mathrm{BU}$ JOB

CATALOG

CCTABLE

CLASSIFIERS

CLASS TABLE

CLUSTERCOLUMNS

CLUSTERS

CODE CONTROLS

COL

COLUMNS

CORPORATE AUTHORS

CORPORATE_INEO

CRTDB

CUSTODIAN REPS

DATADICT

DATE CHECK

DEFAŪLT AUDIT

DEPT

DEPT TABLE

DICTIIONARY

DOC ABSTRACT

DOC CROSSREF

DOC CUSTODIAN

DOC INVENTORY

DOC PROFILE

DOC STATUS

DOC TITLE

DOC TRANTYPE

DRAFTT_STATUS

DTAB

DUAL

DUMMY

EMP

EMPLOYE

EMPLOYEE

ENTITIES

EXTENTS

EZ\$COL

HELPTABLE

IAPAPP

IAPBLK

IAPCOMMENT

IAPELD

IAPMAP

IAPSQLTXT

IAPTRG

IAPTRIGGER

INDEXES

INVENTION

MANUALS

MENU APPLICATION

MENU COMMAND TYPE

MENU HELP
SYNONYY

SYNONYM

SYNONYM

SYNONYM

SYNONYM

SYNONYM

SYNONYM

SYNONYM

SYNONYM

SYNONYM

SYNONYM

SYNONYM

SYNONYM

SYNONYM

SYNONYM

SYNONYM

SYNONYM

SYNONYM

SYNONYM

SYNONYM

SYNONYM

SYNONYM

SYNONYM

SYNONYM

SYNONYM

SYNONYM

SYNONYM

SYNONYM

SYNONYM

SYNONYM

SYNONYM

SYNONYM

SYNONYM

SYNONYY

SYNONYM

SYNONYM

SYNONYM

SYNONYM

SYNONYM

SYNONYM

SYNONYM

SYNONYM

SYNONYM

SYNONYM

SYNONYM

SYNONYM

SYNONYM

SYNONYM

SYNONYM

SYNONYM

SYNONYM

SYNONYM

SYNONYM

SYNONYM

SYNONYM

SYNONYM

SYNONYM

SYNONYM

SYNONYM

SYNONYM

SYNONYM

SYNONYM

SYNONYM 
-5 PUBLIC

-22 PUBLIC

-3 PUBLIC

-24 PUBLIC

-3 PUBLIC

-24 PUBIIC

-22 PUBLIC

-16 PUBLIC

-21 PUBLIC

-8 PUBLIC

-22 PUBIIC

-7 PUBLIC

-5 PUBLIC

-2 PUBLIC

-22 PUBLIC

-22 PUBLIC

-5 PUBLIC

-18 PUBLIC

-15 PUBLIC

-11 PUBLIC

-19 PUBLIC

-12 PUBLIC

-22 PUBLIC

-17 PUBLIC

-16 PUBLIC

-3 PUBLIC

-4 PUBLIC

-23 PUBLIC

-8 PUBLIC

-1 PUBLIC

-3 PUBLIC

-2 PUBLIC

-11 PUBLIC

-6 PUBLIC

-9 PUBLIC

-5 PUBLIC

-17 PUBLIC

-17 PUBLIC

-23 PUBIIC

-12 PUBLIC

-15 PUBLIC

-16 PUBLIC

-19 PUBLIC

-14 PUBLIC

-19 PUBLIC

-10 PUBLIC

-11 PUBLIC

-14 PUBLIC

-17 PUBLIC

-2 PUBLIC

-9 PUBLIC

-16 PUBLIC

-13 PUBLIC

-17 PUBLIC

-1 PUBLIC

-20 PUBLIC

-17 PUBLIC

-9 PUBLIC

-11 PUBLIC

-12 PUBLIC

-4 PUBLIC

-14 PUBLIC

-18 PUBLIC
MENU INFO

MENU MESSAGE

MENU OPTION

MENU PARAM

MENU PARAH XREF

MENU USER

MENU WORK CLASS

MGRTA BLE

MONTH TABLE

NATION

NEWINV

PARTITIONS

PCBLDBOM

PCBLDMST

PCPRDMST

PCSCHDOP

PCWORROP

PILOT

PRIVATESYN

PROJECT

PROJECTS

PRO COMM

PRO-OPER

PRO OPERNAM

PRO PRODNAM

PRO STAT

PRO-TRAV

PUBE ICSYN

PURIDESC

PURITEM

PURORDER

PURRECV

PURRECVT

REF VALUES

REPŌRT DESC

SALGRAD̄E

SDD APPLICATION DATASTORES

SDD-APPLICATION MODULES

SDD-APPLICATION SYSTENS

SDD-ARC ENTRIES

SDD ATTR IBUTES

SDD ATTRIBUTE VALUES

SDD CC ATTRIBUTTES

SDD ${ }^{-} \mathrm{CC}^{-}$COLUMNS

SDD CHĀNGE HISTORY

SDD- COLUMNS

SDD COLUMN ALIASES

SDD-COMMON RELATIONSHIPS

SDD-DATAFIOWS

SDD DATASTORES

SDD DESCRIPTIONS

SDD DFLOW ATT USAGE

SDD DOMAIN̄S

SDD DOM COL ATTS

SDD DSTORE ATTT USAGE

SDD ENT TREE

SDD ERRORS

SDD EVENTS

SDD-FILES

SDD EUNCTIONS

SDD FUNCTION MODULE IMPL

SDD FUNC ATTR MATRI $\bar{X}$

SDD INDEX $\bar{X} E S$
SYNONYM

SYNONYM

SYNONYM

SYNONYM

SYNONYM

SYNONYM

SYNONYM

SYNONYM

SYNONYM

SYNONYM

SYNONYM

SYNONYM

SYNONYM

SYNONYM

SYNONYM

SYNONYM

SYNONYM

SYNONYM

SYNONYM

SYNONYM

SYNONYM

SYNONYM

SYNONYM

SYNONYM

SYNONYM

SYNONYM

SYNONYM

SYNONYM

SYNONYM

SYNONYM

SYNONYM

SYNONYM

SYNONYM

SYNONYM

SYNONYM

SYNONYM

SYNONYM

SYNONYM

SYNONYM

SYNONYM

SYNONYM

SYNONYM

SYNONYM

SYNONYM

SYNONYM

SYNONYM

SYNONYM

SYNONYM

SYNONYM

SYNONYM

SYNONYM

SYNONYM

SYNONYM

SYNONYM

SYNONYM

SYNONYM

SYNONYM

SYNONYM

SYNONYM

SYNONYM

SYNONYM

SYNONYM

SYNONYM 
-24 PUBLIC

-24 PUBLIC

-2 PUBLIC

-24 PUBLIC

-8 PUBLIC

-22 PUBLIC

-2 PUBLIC

-16 PUBLIC

-15 PUBLIC

-8 PUBLIC

-2 PUBLIC

-21 PUBLIC

-17 PUBLIC

-15 PUBLIC

-10 PUBLIC

-21 PUBLIC

- 3 PUBLIC

-2 PUBLIC

-1 PUBLIC

-18 PUBLIC

-1 PUBLIC

-24 PUBLIC

-7 PUBLIC

-23 PUBLIC

-16 PUBLIC

-9 PUBLIC

-7 PUBLIC

-6 PUBLIC

-13 PUBLIC

-9 PUBLIC

- 1 PUBLIC

-11 PUBLIC

-9 PUBLIC

-1 PUBLIC

-14 PUBLIC

-9 PUBLIC

-2 PUBLIC

-6 PUBLIC

-6 PUBLIC

-16 PUBLIC

-4 PUBLIC

-16 PUBLIC

-4 PUBLIC

-19 PUBLIC

-6 PUBLIC

-18 PUBLIC

-25 PUBLIC

-5 PUBLIC

-14 PUBLIC

-12 PUBLIC

-23 PUBLIC

-24 PUBLIC

-24 PUBLIC

-11 PUBLIC

-12 PUBLIC

-13 PUBLIC

14461 SCOTT

14480 SCOTT

14490 SCOTT

14525 SCOTT

4918 SCOTT

7101 SCOTT

14535 SCOTT
SDD INDEX ENTRIES

SDD MENU

SDD MODULES

SDD_MOD_COL_USAGE

SDD NOTES

SDD RELATIONSHIP ENDS

SDD RELATION SELECTIONS

SDD RELEASE NOTES

SDD RESERVE $\bar{D}$ NAMES

SDD SELECT TEXT

SDD- SPACE DEEINITIONS

SDD - SYNONYYMS

SDD TABLE KODUTE USAGE

SDD TAB DEFS

SDD TERM̆S

SDD TRIGGER REES

SDD UNIQUE IDENTIFIER ENTRIES

SDD_VALIDATION_RULES

SDD-VRELENDS

SDD WEIGHTING. FACTORS

SDD WHERE CONDITIONS

SEQN̄OS

SESSIONS

SPACES

SPACETBL

STORAGE

SYNONYMS

SYSAUDIT TRAIL

SYSCATALŌG

SYSCOLAUTH

SYSCOLUHNS

SYSEXTENTS

SYSINDEXES

SYSPROGS

SYSSTORAGE

SYSTABALLOC

SYSTABAUTH

SYSTEM AUDIT

SYSUSERAAUTH

SYSUSERLIST

SYSVIEWS

TAB

TABALLOC

TABLES

TABLE AUDIT

TABQUOTAS

TAB ENTS

TIMĒHOURS

TIMESHEETS

TITLE ABSTR

TRAC2I

USAGE

VIEWS

XTRAC21

XTRAC22

XTRAC23

APPEUNC

APPLICATION ENTITIES

APPLICATION FUNCTIONS

APPLICATION_TABLES

BONUS

CLIENT

CODE CONTROLS
SYNONYM

SYNONYM

SYNONYM

SYNONYM

SYNONYM

SYNONYM

SYNONYM

SYNONYM

SYNONYM

SYNONYM

SYNONYM

SYNONYM

SYNONYM

SYNONYM

SYNONYM

SYNONYM

SYNONYM

SYNONYM

SYNONYM

SYNONYM

SYNONYM

SYNONYM

SYNONYM

SYNONYM

SYNONYM

SYNONYM

SYNONYM

SYNONYM

SYNONYM

SYNONYM

SYNONYM

SYNONYM

SYNONYM

SYNONYM

SYNONYM

SYNONYH

SYNONYM

SYNONYM

SYNONYM

SYNONYM

SYNONYM

SYNONYM

SYNONYM

SYNONYM

SYNONYM

SYNONYM

SYNONYM

SYNONYM

SYNONYM

SYNONYM

SYNONYM

SYNONYM

SYNONYM

SYNONYM

SYNONYM

SYNONYM

VIEW

TABLE

TABLE

TABLE

TABLE

TABIE

TABLE 
TAB\$RBA OWNER

- 4908 SCOTT

14545 SCOTT

4898 SCOTT

14555 SCOTT

1311 SCOTT

7111 SCOTT

14470 SCOTT

7121 SCOTT

7131 SCOTT

7141 SCOTT

7057 SCOTT

6991 SCOTT

14590 SCOTT

15517 SCOTT

4928 SCOTT

6097 SCOTT

14600 SCOTT

14610 SCOTT

14620 SCOTT

14630 SCOTT

14640 SCOTT

14675 SCOTT

14685 SCOTT

14720 SCOTT

14755 SCOTT

14765 SCOTT

14825 SCOTT

15523 SCOTT

14835 SCOTT

14870 SCOTT

14880 SCOTT

14915 SCOTT

14937 SCOTT

14947 SCOTT

14957 SCOTT

14967 SCOTT

14977 SCOTT

15012 SCOTT

15022 SCOTT

15032 SCOTT

15067 SCOTT

15077 SCOTT

15112 SCOTT

15122 SCOTT

15132 SCOTT

15142 SCOTT

15177 SCOTT

15212 SCOTT

15222 SCOTT

15257 SCOTT

15267 SCOTT

15277 SCOTT

14196 SCOTT

15287 SCOTT

15297 SCOTT

15307 SCOTT

15367 SCOTT

15377 SCOTT

15412 SCOTT

15422 SCOTT

15432 SCOTT

15467 SCOTT

15520 SCOTT
TAB\$NAME

TAB\$TYP

DEPT

DUMMY

EMP

ENTITIES

EZCONTROL

LINEITEMS

IINE ITEMS

ORDE $\bar{R} S$

PRICELIST

PRODUCT

PROJECT

OMX INTERNAL DATA

REF VALUES

ROSTER

SALGRADE

SDD ALT REYY ENTRIES

SDD-APPEICATION DATASTORES

SDD $-A P P L I C A T I O N N^{-}$MODULES

SDD-APPLICATION SYSTEMS

SDD ARC ENTRIES

SDD ATTRIEUTES

SDD ATTRIEIUTE VALUES

SDD CC ATIRIBUTTES

SDD-CC COLUMNS

SDD CHANGE: HI STORY

SDD-COLUMNS

SDD COLUMN ALIASES

SDD COMMON RELATIONSHIPS

SDD-DATAFI,ŌWS

SDD-DATASIORES

SDD-DESCRI:PTIONS

SDD DFLOW ATT USAGE

SDD DOMAINMS

SDD DOM COL ATTS

SDD DSTORE: ĀTT USAGE

SDD ENT TREE

SDD ERRŌRS;

SDD EVENTS;

SDD FILES

SDD FUNCTI:ONS

SDD FUNCTION MODULE IMPL

SDD FUNC ATT $\bar{R}$ MATRI $\bar{X}$

SDD INDEX $\bar{X}$ -

SDD INDEX ENTRIES

SDD MENU

SDD MODULES

SDD MOD COL USAGE

SDD NOTES

SDD RELATIONSHIP ENDS

SDD RELATION SELECTIONS

SDD RELEASE NNOTES

SDD RESERVED NAMES

SDD ${ }^{-}$ROW IDENTTIFIERS

SDD SELECT? TEXT

SDD SPACE DEFINITIONS

SDD SYNONȲMS

SDD TABLE MODULE USAGE

SDD TAB DEFS

SDD TERM̄S

SDD_TRIGGER REFS

SDD UNIOUE IDENTIFIER ENTRIES

SDD_VALIDATION_RULES

SDD_VRELENDS
TABLE

TABLE

TABLE

TABLE

TABLE

TABLE

TABLE

TABLE

TABLE

TABLE

TABLE

TABLE

TABLE

VIEW

TABLE

TABLE

TABLE

TABLE

TABLE

TABLE

TABLE

TABLE

TABLE

TABLE

TABLE

TABLE

TABLE

VIEW

TABLE

TABLE

TABLE

TABLE

TABLE

TABLE

TABLE

TABLE

TABLE

TABLE

TABLE

TABLE

TABLE

TABLE

TABLE

TABLE

TABLE

TABLE

TABLE

TABLE

TABLE

TABLE

TABLE

TABLE

TABLE

TABLE

TABLE

TABLE

TABLE

TABLE

TABLE

TABLE

TABLE

TABLE

VIEW 
SEOÑOS

STATUSCODE

TAB ENTS

15497 SCOTT

15507 SCOTT

15877 SDDACCOUNT

12562 SDDACCOUNT

12572 SDDACCOUNT

12592 SDDACCOUNT

12612 SDDACCOUNT

12632 SDDACCOUNT

12642 SDDACCOUNT

12672 SDDACCOUNT

14927 SDDACCOUNT

13027 SDDACCOUNT

13077 SDDACCOUNT

12582 SDDACCOUNT

12602 SDDACCOUNT

12717 SDDACCOUNT

12727 SDDACCOUNT

12737 SDDACCOUNT

12957 SDDACCOUNT

13107 SDDACCOUNT

12747 SDDACCOUNT

$13037^{\circ}$ SDDACCOUNT

13140 SDDACCOUNT

12977 SDDACCOUNT

13007 SDDACCOUNT

12622 SDDACCOUNT

12987 SDDACCOUNT

12757 SDDACCOUNT

12767 SDDACCOUNT

13017 SDDACCOUNT

12777 SDDACCOUNT

12787 SDDACCOUNT

12797 SDDACCOUNT

13097 SDDACCOUNT

12652 SDDACCOUNT

12807 SDDACCOUNT

12997 SDDACCOUNT

12817 SDDACCOUNT

12827 SDDACCOUNT

13127 SDDACCOÚNT

12837 SDDACCOUNT

13087 SDDACCOUNT

12662 SDDACCOUNT

12707 SDDACCOUNT

13057 SDDACCOUNT

13117 SDDACCOUNT

13067 SDDACCOUNT

15637 SDDACCOUNT

13047 SDDACCOUNT

12947 SDDACCOUNT

12907 SDDACCOUNT

12847 SDDACCOUNT

12917 SDDACCOUNT

12967 SDDACCOUNT

12857 SDDACCOUNT

12867 SDDACCOUNT

12877 SDDACCOUNT

13137 SDDACCOUNT

12887 SDDACCOUNT
USA $\overline{G E}$

APPFUNC

APPLICATION ENTITIES

APPLICATION FUNCTIONS

APPLICATION TABLES

CODE CONTROTS

DUMM $\bar{Y}$

ENTITIES

REF VALUES

SDD ALT KEY ENTRIES

SDD APPIIICATION DATASTORES

SDD-APPLICATION MODULES

SDD APPLICATION SYSTEMS

SDD ARC ENTRIES

SDD ATTRIBUTES

SDD ATTRIBUTE VALUES

SDD CC ATTRIBUTTES

SDD CC COLUMNS

SDD CHĀNGE HISTORY

SDD COLUMNS

SDD COLUMN ALIASES

SDD COMMON RELATIONSHIPS

SDD DATAFLŌWS

SDD-DATASTORES

SDD-DESCRIPTIONS

SDD_DFLOW ATT_USAGE

SDD DOMAIÑS

SDD DOM COL ATTS

SDD DSTORE ATT USAGE

SDD ENT TREE

SDD ERRORS

SDDEVENTS

SDD FILES

SDD-FUNCTIONS

SDD FUNCTION MODULE IMPL

SDD FUNC ATT $\bar{R}$ MATRI $\bar{X}$

SDD INDEX̄ES

SDD INDEX ENTRIES

SDD MENU

SDD MODULES

SDD MOD COL USAGE

SDD NOTES

SDD RELATIONSHIP ENDS

SDD RELATION SELECTIONS

SDD RELEASE NOTES

SDD RESERVED NAMES

SDD ROW IDENTIFIERS

SDD SELECT TEXT

SDD SPACE DEFINITIONS

SDD SYNONYMS

SDD TABLE MODULE USAGE

$S D D$ TAB DEFS

SDD TERMS

SDD TRIGGER REFS

SDD UNIQUE IDENTIFIER ENTRIES

SDD VALIDATION RULES

SDD VRELENDS

SDD WEIGHTING FACTORS
TABIE

TABLE

TABLE

TABLE

VIEW

TABLE

TABLE

TABLE

TABLE

TABLE

TABLE

TABLE

TABLE

TABLE

TABLE

TABLE

TABLE

TABLE

TABLE

TABLE

TABLE

TABLE

TABLE

TABLE

VIEW

TABLE

TABLE

TABLE

TABLE

TABLE

TABLE

TABLE

TABLE

TABLE

TABLE

TABLE

TABLE

TABLE

TABLE

TABLE

TABLE

TABLE

TABLE

TABLE

TABLE

TABLE

TABLE

TABLE

TABLE

TABLE

TABLE

TABLE

TABLE

TABLE

TABLE

TABLE

TABLE

TABLE

TABLE

VIEW

TABLE 
TAB\$RBA OWNER

\begin{aligned} &-12897 SDDACCOUNT \\ & \hline 12927 SDDACCOUNT \\ & 12937 SDDACCOUNT \\ & 180 SYS \\ & 45 SYS \\ & 15 SYS \\ & 2051 SYS \\ & 25 SYS \\ & 160 SYS \\ & 100 SYS \\ & 150 SYS \\ & 120 SYS \\ & 130 SYS \\ & 170 SYS \\ & 140 SYS \\ & 90 SYS \\ & 35 SYS \\ & 15 SYS \\ & 11049 SYS \\ & 16076 SYS \\ & 18311 SYS \\ & 18551 SYS \\ & 18791 SYS \\ & 18931 SYS \\ & 110 SYS \\ & 222 SYS \\ & 231 SYS \\ & 228 SYS \\ & 216 SYS \\ & 213 SYS \\ & 234 SYS \\ & 219 SYS \\ & 225 SYS \\ & 210 SYS \\ & 237 SYS \\ & 80 SYS \\ & 200 SYS \\ & 190 SYS. \\ & 502 SYSTEM \\ & 452 SYSTEM \\ & 496 SYSTEM \\ & 490 SYSTEM \\ & 493 SYSTEM \\ & 487 SYSTEM \\ & 333 SYSTEM \\ & 345 SYSTEM \\ & 342 SYSTEM \\ & 431 SYSTEM \\ & 327 SYSTEM \\ & 705 SYSTEM \\ & 695 SYSTEM \\ & 620 SYSTEM \\ & 650 SYSTEM \\ & 446 SYSTEM \\ & 9974 SYSTEM \\ & 505 SYSTEM \\ & 10444 SYSTEM \\ & 9984 SYSTEM \\ & 715 SYSTEM \\ & 437 SYSTEM \\ & 440 SYSTEM \\ & 290 SYSTEM \\ & 1165 SYSTEM \\ & \\ & \hline 190\end{aligned}

TAB\$NAME

TAB\$TYP

SDD WHERE CONDITIONS TABLE

TAB-ENTS - TABLE

USAGGE

AUDIT TRAIL

COLAUTH

COLUMNS

DBLINRS

EXTENTS

FILES

INDEXES

PARTITIONS

PROGS

PROG STMNT'S

SEGQUUOTAS

SPACEMAP

SPACES

TABAUTH

TABLES

TEMP 2\$1

TEMP $2 \$ 2$

TEMP $2 \$ 3$

TEMP2\$ 4

TEMP $2 \$ 5$

TEMP $2 \$ 6$

USERAUTH

V4EXPCIUS

V4EXPCOL

VAEXPEXTENTS

V4EXPINDEX.

V4EXPSPACE

V4EXPSYN

V4EXPTAB

V4EXPTABAUTH

V4EXPUSER

V4EXPVIEW

VIEWS

default_auditing_options_

system_auditing_options_-

ĀUDIT_AC̄CESS

AUDIT ACTIONS

AUDIT CONNECT

AUDIT DBA

AUDIT EXISTS

AUDIT TRAIL

CATALŌG

CLUSTERCOLUMNS

CLUSTERS

COL

COLUMNS

CRT

CRTBOX

CRT PRODUCTS

CRT TYPE

DEEÄULT_AUDIT

DEPT

DTAB

DUAL

EMP

ESC

EXPTAB

EXPVEW

EXTENTS

EZ\$COL
TABLE

TABLE

TABLE

TABLE

TABLE

TABLE

TABLE

TABLE

TABLE

TABLE

TABLE

TABLE

TABLE

TABLE

TABLE

TABLE

TABLE

TABLE

TABLE

TABLE

TABLE

TABLE

TABLE

VIEW

VIEW

VIEW

VIEW

VIEW

VIEW

VIEW

VIEW

VIEW

VIEW

TABLE

TABLE

TABLE

VIEW

TABLE

VIEW

VIEW

VIEW

VIEW

VIEW

VIEW

VIEW

VIEW

VIEW

TABLE

TABLE

TABLE

TABLE

VIEW

TABLE

TABLE

TABIE

TABLE

TABLE

VIEW

VIEW

VIEW

TABLE 
TAB\$RBA OWNER

TAB\$NAME

TAB\$TYP

1345 SYSTEM

EZCONTROL

TABLE

1385 SYSTEM

FUNCTIONS

TABLE

660 SYSTEM

750 SYSTEM

246 SYSTEM

1035 SYSTEM

1045 SYSTEM

1130 SYSTEM

1055 SYSTEM

1095 SYSTEM

1085 SYSTEM

1075 SYSTEM

1065 SYSTEM

339 SYSTEM

10019 SYSTEM

640 SYSTEM

7661 SYSTEM

7681 SYSTEM

7631 SYSTEM

7611 SYSTEM

7671 SYSTEM

7621 SYSTEM

7641 SYSTEM

7651 SYSTEM

7591 SYSTEM

7601 SYSTEM

318 SYSTEK

14464 SYSTEM

5003 SYSTEM

4993 SYSTEM

7296 SYSTEM

2416 SYSTEM

425 SYSTEM

10524 SYSTEM

397 SYSTEM

6691 SYSTEM

1285 SYSंTEM

499 SYSTEM

321 SYSTEM

287 SYSTEM

394 SYSTEM

330 SYSTEM

382 SYSTEM

324 SYSTEM

284 SYSTEM

336 SYSTEM

391 SYSTEM

281 SYSTEM

275 SYSTEM

379 SYSTEM

443 SYSTEM

385 SYSTEM

$3 \& 8$ SYSTEM

370 SYSTEM

$42 \%$ SYSTEM

278 SYSTEM

449 SYSTEM

434 SYSTEM

10184 SYSTEM

10584 SYSTEM

348 SYSTEM

GOTO_LC

TABLE

TABLE

HELPTABLE

TABLE

IAPAPP

IAPBLK

IAPCOMMENT

IAPFLD

IAPMAP

IAPSQLTXT

IAPTRG

IAPTRIGGER

INDEXES

IINE ITEMS

TABLE

TABLE

TABLE

TABLE

TABLE

TABLE

TABLE

TABLE

VIEW

LORC

MENU APPLICATION

TABLE

TABLE

MENU_COMMAND_TYPE

TABLE

MENU HELP

MENU INEO

MENU MESSAGE

MENU OPTION

MENU PARAM

MENU PARAM XREF

MENU_USER

MENU WORR CLASS

PARTITTIONS

PCBLDBOM

PCBLDMST

PCPRDMST

PCSCEDOP

PCWORROP

PRIVATESYN

PROJECT

PUBLICSYN

QMX INTERNAL DATA

TABLE

TABLE

TABLE

TABLE

TABLE

TABLE

TABLE

TABLE

TABLE

VIEW

TABLE

TABLE

TABLE

TABLE.

TABLE

VIEW

TABLE

VIEW

SEQN̄OS

SESSIONS

SPACES

STORAGE

SYNONYMS

SYSCATALOG

SYSCOLAUTH

SYSCOLUMNS

SYSEXTENTS

SYSINDEXES

SYSPROGS

SYSSTORAGE

SYSTABALIOC

SYSTABAUTH

SYSTEM AUDIT

SYSUSER̄AUTH

SYSUSERLIST

SYSVIEWS

TAB

TABALLOC

TABLE AUDIT

TABQUOTTAS

TEST

TIMEHOURS

TABLE

TABLE

VIEW

VIEW

VIEW

VIEW

VIEW

VIEW

VIEW

VIEW

VIEW

VIEW

VIEW

VIEW

VIEW

VIEW

VIEW

VIEW

VIEW

VIEW

VIEW

VIEW

VIEW

TABLE

TABLE

VIEWS

VIEW

1006 records selected. 


\section{Appendix D}

SDD Entity and Attribute Report 


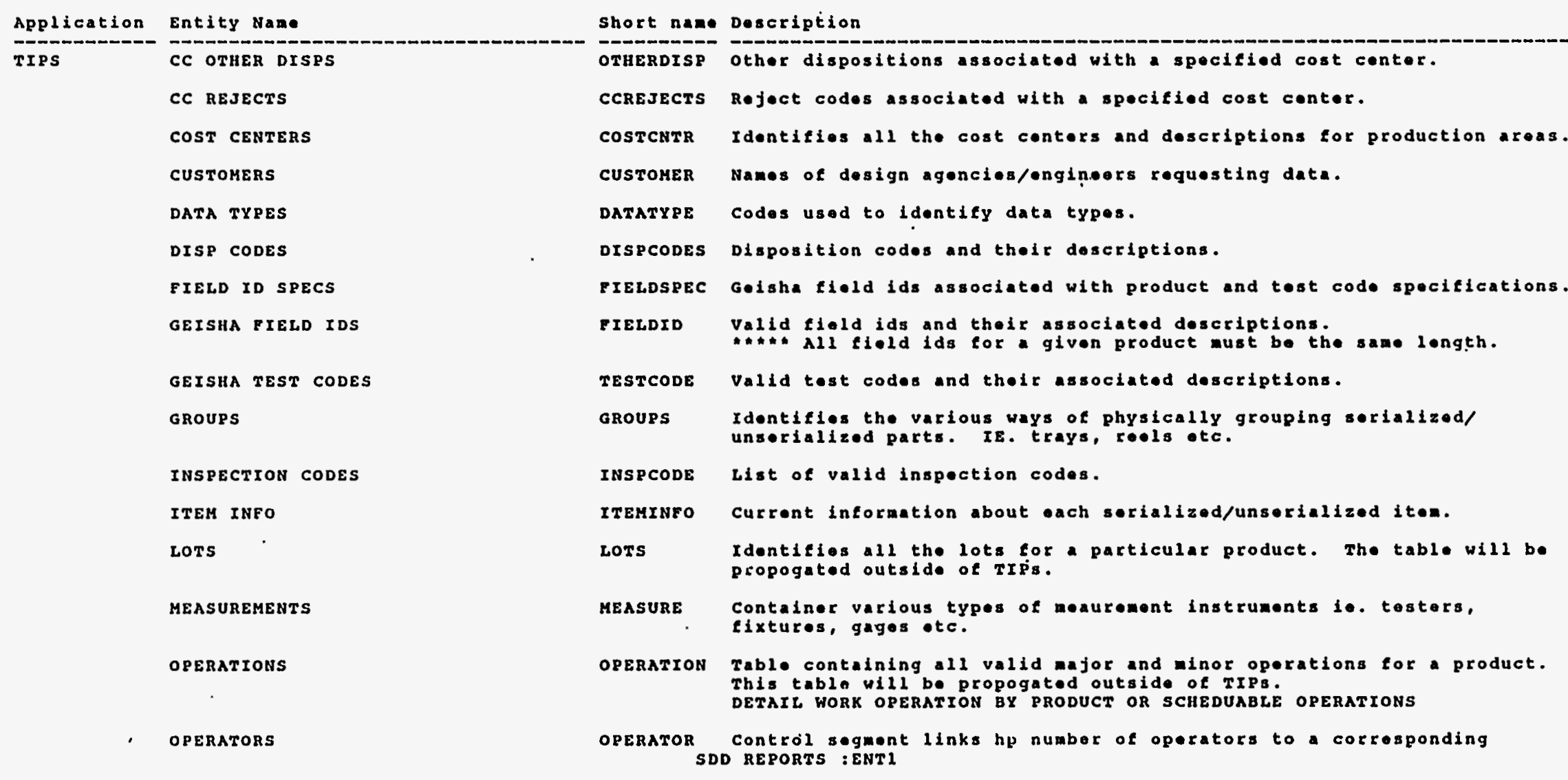




Application Entity Mamo
TIPS

short name Description

OPERATOR tips roading.

OT́HER DISP CODES

PRODUCTS

QC NUMBERS

REJECT CODES

REJECTS

REQUESTORS

REWORK CODES

REWORKS

SOURCE CODES

SUB LOTS

TEST CODE SPECS

TEST SPECS
Identifies valid disposition codes which can be used on the tips syston.

PRODuct This table will be propogated outside of TIPS.

ThIs table WIII be propogatod outside of TIRS.
THIS ENTITY IS YN PROCODE AS PRODUCT MASTER.

THAT WILL BE A CROSS REFERENCE FOR OTHER PRODUCTS.

INCLUDES BUILD, PURNISH, PURCHASED PRODUCTS

TO ALL OTHER PRODUCTION ENTITIES AND TABLES

QCNUMBER Control segment linking qc numbers with apecific tips reading.

REJECTCODE Reject codes and associated descriptions.

REJECT Identifies the rejects pertormed on one or more items.

REQUESTOR Control segment linking customers to thatr desired deta reporting requirements.

REWORKCDS Identifles valid rowork codes and their descriptions.

REWORK. Rework intormation for a specific serial number/iton.

source Identifios valid data sources and thoix descriptions.

- product acceptance

q - surveillance data

etc.

sublot Decribes the different ways part/itens may be grouped logically together. $\bullet x$. blocko, sub-lots, runs, etc.

codespec Goisha tost codes and their associated information for each drawing/ product specification.

TESTSPEC Contains an occurance for each vorsion of arawing number or product specification or a test spocification. SDD REPORTS :ENT? 
Date: 26-JUL-88

Application Entity Name

TIPS TIPS

TIPS
ORACLE

SQL DESIGN DICTIONARY

Entities and Description

Short nane Description

TIPS

Contains all the reading/wavefora data collected in TIPs.

SDD REPORTS :ENTI 
SOL DESTGN DICTIONARY

Detailed Entity/Attribute listing

Application
TIPS
Attribute Name

cC DISP ID

COST CENTER ID

OTHER DISP CODE

CC REJECTS

COST CENTERS

CUSTOMERS

CUSTOMER ID
CC REJECT ID

REJECT CODE

Cost CENTER ID

COST CENTER

COST CENTER DESCRIPTION

primary key - generated id. Identifies valid cost conters.

Description of cost contor.

Primary key - generated id. oreign key - links ce rejects to cost conter table.

Foralgn key - links ce rejects to reject

$\begin{array}{llr}M & \text { IN } & 10 \\ Y & \mathrm{CH} & 4\end{array}$

CUSTOMER NAME

CUSTOMER ADDRESS
CUSTOMER LOCATION

\section{N IN 10 Primary key - gonerated id. \\ Foreign koy - links cc othor disp to}

Forelgn key - links ce other disp to Foreign key - links ce
other disp code table.

SDD REPORTS : ATTRIB14

Primary key - generated id.

Name of the design agency or engineer. Address of site.

location/site of were the data will be sont to. 
SOL - DESIGN DICTIONARY Detailed Entity/Attribute Listing

Application Entity

TIPS DATA TXPES

DISP CODES

FIELD ID SPECS

\section{DATA TYPE}

DATA TYPE DESCRIPTION

DISP CODE

DISP DESCRIPTION

CONTROL ID

TEST SPEC ID

TEST CODE SPEC ID

SPEC UPPER LIMIT

SPEC LOWER LIMIT

$\begin{array}{lll}\text { N } & \mathrm{CH} & 1 \\ \times & \mathrm{CH} & 20\end{array}$

N

Y $-\mathrm{CH} 20$

$\begin{array}{lll}\text { N } & \text { IN } & 10 \\ Y & \text { IN } & 10\end{array}$

Y IN 10

× มง

$\times$ พบ

SDD REPORTS : ATTRIBI

Primary key - variable, misc., attribute, date

Description for vach data type.

Prinary key - accept, rojoct, conform, hi, low, hold, doviat.

Description of the disposition code.

Primary koy - gonorated id. Foreign koy - links tiold id spec and tost apoc table.

Foreign key - link: tiold id spoc and test code spec table.

Maximum value allowed by the product specification.

Mininua value allowed by the product specification. 
Date : 26-JUL-88 ORACLE

SOL * DESTGH DICTIOHARY

Detailed Entity/attribute Listing

\begin{tabular}{|c|c|c|c|c|c|c|c|}
\hline \multirow{2}{*}{$\begin{array}{l}\text { Application } \\
\text { TIPs }\end{array}$} & Entity & Attribute Name & opt & $\mathbf{F T}$ & \multirow{2}{*}{$\frac{\operatorname{size}}{10}$} & Dec P1 & Attribute Notas \\
\hline & FIELD ID SPECS & FIELD ID ID & $\mathbf{Y}$ & IN & & & $\begin{array}{l}\text { Foroign koy - links fiold id spoc to } \\
\text { geisha fiold id tablo. }\end{array}$ \\
\hline & & $\begin{array}{l}\text { CNTL LOWER LIMIT } \\
\text { SPC LOWER LIMIT }\end{array}$ & $\mathbf{Y}$ & Nu & & & $\begin{array}{l}\text { Minimum value set for control linits, } \\
\text { Minieum spe value allowed for product } \\
\text { specifications. }\end{array}$ \\
\hline & & SPC UPPER LIMIT & $\mathbf{Y}$ & NU & & & $\begin{array}{l}\text { Maximum spe value allowed for product } \\
\text { specifications. }\end{array}$ \\
\hline & & DATE CHANGED & $\mathbf{Y}$ & DA & & & $\begin{array}{l}\text { Date field id specifleations were } \\
\text { changed. }\end{array}$ \\
\hline & & MIN READINGS & $\mathbf{Y}$ & Nu & & & $\begin{array}{l}\text { Minimum number of readings required for } \\
\text { the tield ld. }\end{array}$ \\
\hline & & CNTL UPPER LIMIT & $\mathbf{Y}$ & ตบ & & & Maximum value set for control linits. \\
\hline & GEISHA FIELD IDS & $\begin{array}{l}\text { FIELD ID ID } \\
\text { GEISHA FIELD ID }\end{array}$ & $\underset{\mathbf{y}}{\mathbf{n}}$ & $\begin{array}{l}\text { IN } \\
\mathbf{C H}\end{array}$ & $\begin{array}{r}10 \\
6\end{array}$ & $\cdot$ & $\begin{array}{l}\text { Primingy key - generated id. } \\
\text { Codo ropresenting a secific type or } \\
\text { reading. }\end{array}$ \\
\hline & & TEST SPEC NUHBER & $\mathbf{x}$ & $\mathbf{C H}$ & 8 & • & $\begin{array}{l}\text { Foroign koy - links golsha tlold ids to } \\
\text { tost spec table. }\end{array}$ \\
\hline & & DATA TYPE & $\mathbf{x}$ & $\mathbf{c H}$ & 1 & & $\begin{array}{l}\text { Poreign key - links golsha tiold lds to } \\
\text { data types table. }\end{array}$ \\
\hline & & FIELD YD DESCRIPI & $\mathbf{y}$ & $\mathbf{C H}$ & 20 & & Description for the field id. \\
\hline
\end{tabular}

SDD REPORTS : ATTRIBIA 
Date: 26-JUL-88

ORACLE

SOL DESIGH DICTTONARY

Dotailed Entity/Attribute Listing

\begin{tabular}{|c|c|c|c|c|c|c|c|}
\hline Application & Entity & Attribute Name & opt & $\mathbf{r T}$ & size & Doc Pl & Attribute Notes \\
\hline \multirow[t]{7}{*}{ TIPS } & GEISHA TEST CODES & $\begin{array}{l}\text { TEST CODE TD } \\
\text { GEISHA TEST CODE } \\
\text { TEST SPEC NUHBER }\end{array}$ & $\begin{array}{l}\mathbf{y} \\
\mathbf{y} \\
\mathbf{y}\end{array}$ & $\begin{array}{l}\text { Nu } \\
\mathbf{C H} \\
\mathbf{C H}\end{array}$ & $\begin{array}{l}2 \\
8\end{array}$ & & $\begin{array}{l}\text { Primary key - generated id. } \\
\text { Code identifyinga specific test. } \\
\text { roreign key - links geisha test codes to } \\
\text { test spec tablo. }\end{array}$ \\
\hline & & TEST CODE DESCRIPTION & $\mathbf{Y}$ & $\mathbf{C H}$ & 20 & & $\begin{array}{l}\text { Description associated with the tast } \\
\text { code. }\end{array}$ \\
\hline & GROUPS & GROUP CODE & N & $\mathbf{C H}$ & 4 & $\cdot \cdot$ & $\begin{array}{l}\text { Prianry key - code identifying physical } \\
\text { groupings of ttems. }\end{array}$ \\
\hline & & GROUP NAME & $\mathbf{x}$ & $\mathrm{CH}$ & 10 & & Describes the type of grouping. \\
\hline & INSPECTION CODES & $\begin{array}{l}\text { INSPECT CODE } \\
\text { INSPECT CODE DESC } \\
\end{array}$ & N & $\begin{array}{l}\mathbf{C H} \\
\mathbf{C H}\end{array}$ & $\begin{array}{l}10 \\
20\end{array}$ & & $\begin{array}{l}\text { Primary key - inspection code } \\
\text { Description of the inspection codes. }\end{array}$ \\
\hline & ITEM INFO & $\begin{array}{l}\text { SERIAL ID } \\
\text { MANUFACTURE CODE }\end{array}$ & $\mathbf{x}$ & $\begin{array}{l}\text { IN } \\
\text { CH }\end{array}$ & $\begin{array}{r}10 \\
6\end{array}$ & & $\begin{array}{l}\text { Primary key-generated id. } \\
\text { Code identifying the manufacturer of an } \\
\text { item. }\end{array}$ \\
\hline & & LOT ID & $\mathbf{x}$ & IN & 10 & & $\begin{array}{l}\text { Foreign key - links } 1 \text { ten info to lot } \\
\text { table. }\end{array}$ \\
\hline
\end{tabular}


SQL - DESIGN DICT Detalled Entity/Attribute Listing

\begin{tabular}{|c|c|c|c|c|c|c|c|}
\hline \multirow{2}{*}{$\begin{array}{l}\text { Application } \\
\text { TIPS }\end{array}$} & Entity & Attribute Name & \multirow{2}{*}{$\stackrel{\text { Opt }}{\mathrm{x}}$} & \multirow{2}{*}{$\overrightarrow{\mathbf{F T}}$} & \multirow{2}{*}{$-s i z e$} & Dec P 1 & Attribute Notes \\
\hline & ITEM INFO & GROUP CODE & & & & & $\begin{array}{l}\text { Foreign key - links item info to group } \\
\text { table. }\end{array}$ \\
\hline & & $\begin{array}{l}\text { SERIAL NUMBER } \\
\text { DATE ASSEMBLED } \\
\text { PRODUCT ID }\end{array}$ & $\begin{array}{l}\mathbf{y} \\
\mathbf{y} \\
\mathbf{y}\end{array}$ & $\begin{array}{l}\text { CH } \\
\text { DA } \\
\text { IN }\end{array}$ & $\begin{array}{l}20 \\
10\end{array}$ & & $\begin{array}{l}\text { Unique identifier of an iten. } \\
\text { Date the itom was assombled. } \\
\text { Foreign key - links item info to product } \\
\text { tabio. }\end{array}$ \\
\hline & & MANUFACTURE DATE CODE & $\mathbf{y}$ & $\mathbf{C H}$ & 3 & . & $\begin{array}{l}\text { Date code identifying when the iter was } \\
\text { manufactured. }\end{array}$ \\
\hline & & $\begin{array}{l}\text { GROUP VALUE } \\
\text { POSITION2 }\end{array}$ & $\begin{array}{l}\mathbf{y} \\
\mathbf{y}\end{array}$ & $\begin{array}{l}\mathbf{C H} \\
\mathbf{C H}\end{array}$ & $\begin{array}{l}9 \\
5\end{array}$ & & $\begin{array}{l}\text { value associated with the group code. } \\
\text { Identifites location of ungerialized } \\
\text { parts found in groups. }\end{array}$ \\
\hline & & DISP CODE & $\mathbf{Y}$ & $\mathbf{C H}$ & 2 & & $\begin{array}{l}\text { Forelgn key - links iten info ind disp } \\
\text { code table. }\end{array}$ \\
\hline & & $\begin{array}{l}\text { DATE CREATION } \\
\text { SUB LOT CODE }\end{array}$ & $\begin{array}{l}\mathbf{Y} \\
\mathbf{Y}\end{array}$ & $\begin{array}{l}\text { DA } \\
\text { CH }\end{array}$ & 5 & & $\begin{array}{l}\text { Date itom was created. } \\
\text { Forelgn key - ilins item lnio to sub lot } \\
\text { table. }\end{array}$ \\
\hline & . & $\begin{array}{l}\text { SUB LOT VALUE } \\
\text { REMARKS }\end{array}$ & $\mathbf{x}$ & $\begin{array}{cr}\mathrm{CH} \\
\mathrm{CH}\end{array}$ & $\begin{array}{l}10 \\
80\end{array}$ & & $\begin{array}{l}\text { Value associated with the sub lot code. } \\
\text { Narrative associated with the given } \\
\text { item/part. }\end{array}$ \\
\hline & & $\begin{array}{l}\text { DISPOSITION REASON } \\
\text { POSITION3 }\end{array}$ & $\begin{array}{l}\mathbf{y} \\
\mathbf{y}\end{array}$ & $\begin{array}{l}\mathbf{C H} \\
\mathbf{C H}\end{array}$ & $\begin{array}{r}20 \\
5\end{array}$ & & $\begin{array}{l}\text { Reason for the current disposition. } \\
\text { Identifios location of unserialized } \\
\text { parts found in groups. }\end{array}$ \\
\hline & & POSITION1 & $\mathbf{Y}$ & $\mathbf{C H}$ & 5 & & $\begin{array}{l}\text { Identifies location of unsorialized } \\
\text { parts found in groups. }\end{array}$ \\
\hline
\end{tabular}


Date: 26-JUL-88

ORACLE

SQI - DESIGN DICTIONARY

Dotailod Entity/attribute listing

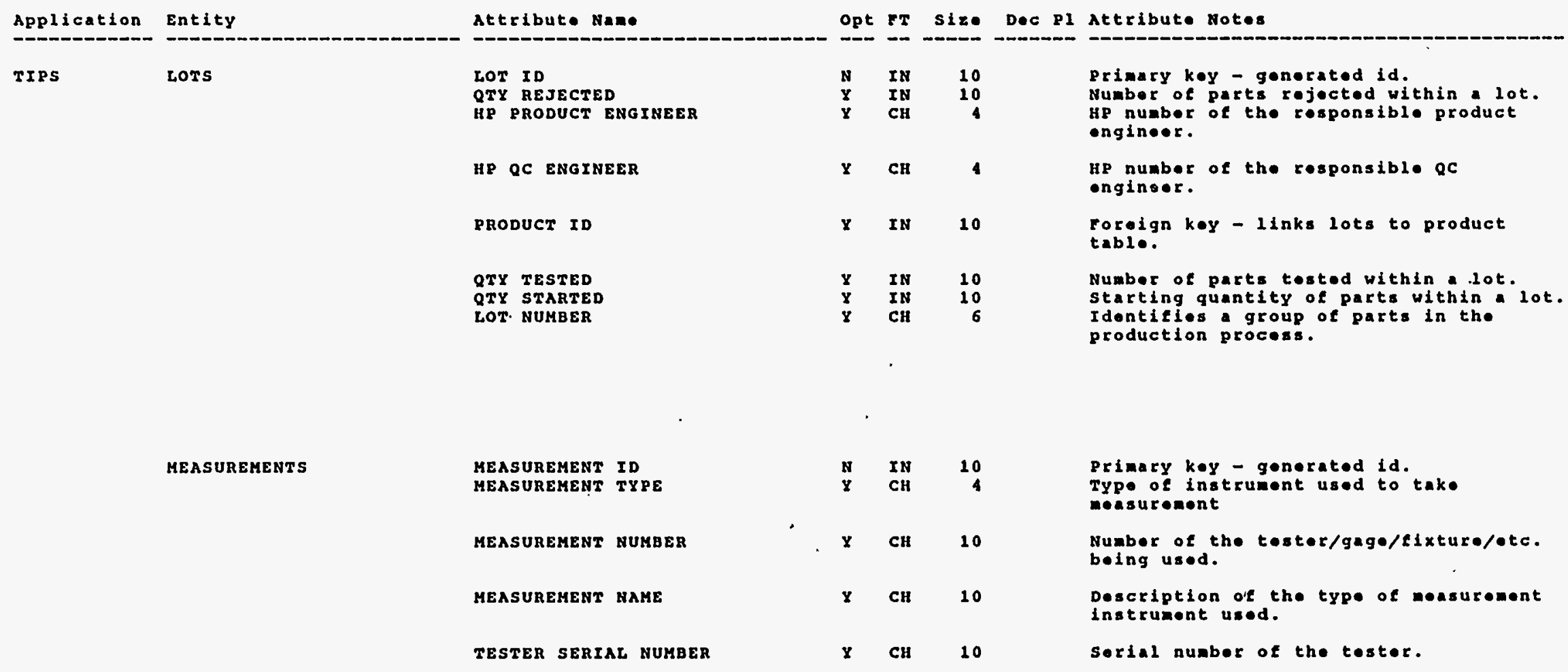

SDD REPORTS : ATTRIB14 
SOL - DESTGN DICTIONARY

Detalled Entity/Attribute Listing

\begin{tabular}{|c|c|c|c|c|c|c|}
\hline Application & Entity & Attribute Name & opt & $\mathbf{P T}$ & S1ze D०C PI & Attribute Wotes \\
\hline \multirow[t]{5}{*}{ TIPS } & OPERATIONS & $\begin{array}{l}\text { OPERATION TD } \\
\text { OPERATION MAJOR }\end{array}$ & $\begin{array}{l}\mathbf{N} \\
\mathbf{Y}\end{array}$ & IN & 10 & $\begin{array}{l}\text { Primary key - generated id. } \\
\text { List of gajor operations for a specific } \\
\text { product. }\end{array}$ \\
\hline & & OPERATION MINOR & $\mathbf{y}$ & $\mathbf{c H}$ & 4 & $\begin{array}{l}\text { List of minor operations cor a specific } \\
\text { product. }\end{array}$ \\
\hline & & PRODUCT IO & $\mathbf{y}$ & In & 10 & $\begin{array}{l}\text { Poreign key - links operation and } \\
\text { product table. }\end{array}$ \\
\hline & & OPERATION SEQUENCE & $\mathbf{y}$ & $\mathrm{Cr}$ & 6 & $\begin{array}{l}\text { sequence number of the operation within } \\
\text { the production process. }\end{array}$ \\
\hline & & OPERATION DESCRIPTION & $\mathbf{Y}$ & $\mathbf{C H}$ & 30 & $\begin{array}{l}\text { Detailed doscription of the major and } \\
\text { minor operations. }\end{array}$ \\
\hline
\end{tabular}

OPERATORS

OPERATOR ID

TIPS ID

$\begin{array}{rrr}N & \text { IN } & 10 \\ \mathrm{CH} & 4\end{array}$

Y IN 10
N

cu

10
Primary key - generated id.

Hp number of the operator performing the reading.

Foreign key - links operator to tips roadings table.

Primary key - identifies the disposition of the reject. 
Date: 26-JUZ-88

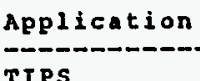

Entity

OTHER DISP CODES

Attribute Nane

OTHER DISP DESCRIPTION

ORACLE

SQL DESIGN DICTIONARY

Dotailed Entity/attribute Listing
Opt FT size Dec pl Attribute Notes

Description of the other disposition code.
PRODUCTS

QC NUMBERS

REJECT CODES

REJECT CODE

REJECT CODE DESCRIPTION

PRODUCT ID PRODUCT NAME

QC ID

TIPS ID

QC NUMBER
$\begin{array}{ll}\mathbf{N} & \mathrm{IN} \\ \mathbf{X} & \mathbf{C} \\ \mathbf{C} & \mathbf{C}\end{array}$

Primary keY - generated ld

$\begin{array}{ll}\mathbf{I} \\ \mathbf{Y} & \mathbf{I N}\end{array}$

$\times$ No

10

10
10

12

MRC code identifying a product.
Identifies a weapon part - MC number

Primary key - generated id.

coreign koy - links qc number to tips

Qc numbers associated with apecific tips raading.

Primary key - identifies the reason a part was rejected.

Description for the reject code. 
DAte: 26-JUL-88

$\frac{\text { Application }}{\text { TIRS }}$

REQUESTORS

REWORK CODES
Attribute Namo

REJECT ID

REJECT CODE

REJECT AREA CODE

SXR NUMBER

OTHER DISP CODE

COST CENTER ID

y IN

REQUESTOR ID
CUSTOMER ID

CONTROE ID

$\mathbf{N}$ IN

10
10

$\times$ IN

10

REWORK CODE

v $\mathrm{CH}$

REWORK CODE DESCRIPTION SDD RERORTS : ATTRIBIL
Sire Dec PI Attribute Notes

Primary key - generated id.

Foreign key - links reject and reject code table.

Identifies the area the reject code was assignod.

Identifies sxR number written against acceptable rejects.

For•lgn key - links reject and reject disp codo table.

Foreign key - links reject and cost conter tabie.

Primary key - generated id.

Foraign key - links requestor to customor table.

Forelgn key - links requestor to tield id spec table.

Primary key - identifies the reason part was reworked.

Description of the rework code. 

REWORK ID

REWORK DATE CODE

REWORK SUFFIX

REWORK MANUFACTURE CODE

REWORK CODE

SOURCE CODE

SOURCE CODE DESCRIPTION

SUB LOTS
SUB LOT CODE

SUB LOT NAME

w

y $\quad$ cH

$\mathbf{C} \quad \mathbf{c H}$

Y $\mathrm{CH}$

$\mathbf{C} \quad \mathbf{C H}$

6

2

$\times \quad \mathrm{CH} \quad 20$

$\cdot$

ch

SDD REPORTS : $\underset{\text { ATTRIBLA }}{\mathbf{C H}}$
Primary key - generated id. The number of the SIER written to

The date code of anit which was rework•d.

Idontified rotroactive changes. accomplished by retrofit.

Manufacture code of manufacturer other than the original manue.

Rework code.

Primary key - Identifies the data source of the roading.

Description of the source code.

Primary key - code identifying sub lots of parts/items

Describes the type of sub-lots. 
Date: 26-JUL-88

ORACLE

SQL - DESIGN DICTIONARY

Dotalled Entity/Attributo histing

Application

Entity

Attribute Name

Opt PT Size Dec PI Attribute Notes

TIPS

TEST CODE SPECS

TEST CODE SPEC ID

FORM TITLE

DATE CHANGED

$\begin{array}{lll}\mathbf{N} & \text { IN } & 10 \\ \mathbf{Y} & \mathrm{CH} & \mathbf{2 0} \\ \mathbf{Y} & \mathrm{DA} & \\ & & \\ \mathbf{X} & \mathrm{NU} & \\ \mathbf{Y} & \mathbf{I N} & 10 \\ & & \\ \mathbf{Y} & \mathbf{N U} & \end{array}$

DATE CHANGED

REPORT LEVEL

$\mathbf{x}$

TEST CODE ID

TEST SPECS

TEST SPEC ID

TEST SPEC PREFIX

DATE CHANGED

$\stackrel{\mathbf{Y}}{\mathbf{Y}}$

IN $\quad 10$

10

$\mathbf{D} \boldsymbol{A}$

TEST SPEC ISSUE

TEST SPEC SUFPIX

$\mathbf{Y}$

cil 4

TEST SPEC NUMBER

CH

$\mathbf{C H}$

SDD REPORTS : ATTRIB14

Primary key - generated id.

changed.

Reporting level for RoX data.

roroign koy - links tost code spec to tost spoc table.

Forolgn key - links test codo spec to golsha test code table.

Primary key - generated id.

profix associated with

drawing/product/tost spoc document.

Date drawing/product/test specification information changed.

Issue associated with a

drawing/product/test spec document.

suffix associated with a

drawing/product/test spec document.

Identifies a drawing/product/test

specification docunent. 
TIPS ID

READTHG ATTRIBUTE

READING MISC

MEASUREMENT ID

SUB LOT VALUE

SUB LOT CODE

GROUP CODE

PRODUCT CODE

TESTER ADAPTO

POSITION2

INSPECT CODE

REJECT ID

COMMENTS

SOURCE CODE

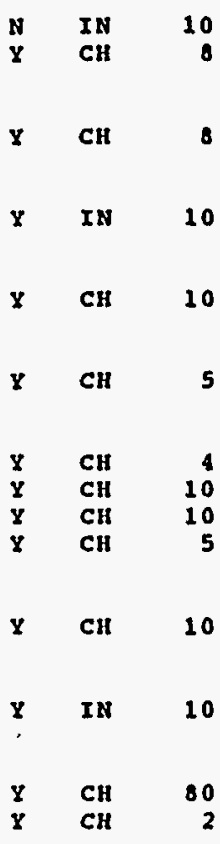

SOD REPORTS : ATTRIB14 primary key - generated id. Data value associated with attribute typo fiold ids.

Data value associated with miscellaneous typ. field ids.

roreign key - links tips to moasurement table.

value of the sub lot at the time of the reading.

Foreign key - links tips to sub lot table.

roreign koy - links tips to group table. MRC code identifying a product.

Apaptor for tostor porforming tost. Identifies location of unserialized parts found in groups.

Foreign key - links tips to inspect codes table.

Foreign key - links tips to reject table.

Narrative associated with the reading. rorelgn key - links tips to source code table. 
Date: 26-JUL-88

ORACLE

SQL - DESIGN DICTIONARY

Dotailod Entity/Attribute Listing

Application

TIRS

TrPS

\section{Attribute Nane}

ATTEMPT NUMBER

DATE TRANSHITTED

ULTIMATE DISPOSITIOA

SUBASSEMBLY SERTAL ID

ROA LEVEL

CONTROL ID

MDS TRAVELER NUMBER

READING VARIABLE

ATTEMPT SWITCH

POSTTION 3

OPERATION ID

READING DATE

DISP CODE

REWORK ID
Opt FT Size Dec PI Attribute Hotes

sequence number for a product being

Date data was transmitted.

Final disposition of an iter - (DACI).

Foroign koy - sorial id of a subassombly

Level of containment of the subassembly

Foreign key - links tips to thofield id spec table.

Travelor numbers associated with MDS data.

Data value associated with numoric type tield ids.

?ว????

Identifies location of unsorialized parts tound in groups.

Foreign key - links tips to operation table.

Data value associated with date type field ids.

Foreign key - links tips to disposition code table.

Foreign key - links tips to rowork table. 
SQL - DESIGI DTCTIONARY

Detallod Entity/Attribute Listing

\begin{tabular}{|c|c|c|c|c|c|c|}
\hline Application & Entity & Attribute Name & opt & $\mathbf{F T}$ & Sizo DeC PI & Attribute Notes \\
\hline \multirow[t]{3}{*}{ TIPS } & TIPS & $\begin{array}{l}\text { READING WAUEYORM } \\
\text { DATE TEST } \\
\text { POSITIONI }\end{array}$ & $\begin{array}{l}\mathbf{y} \\
\mathbf{y} \\
\mathbf{X}\end{array}$ & $\begin{array}{l}\text { Nu } \\
\text { DA } \\
\text { CH }\end{array}$ & 5 & $\begin{array}{l}\text { Digital waveform data. } \\
\text { Date and time stamp of the raading. } \\
\text { Identifios location of unserialized } \\
\text { parts found in groups. }\end{array}$ \\
\hline & & GROUP VALUE & $\mathbf{Y}$ & $\mathrm{CH}$ & 9 & $\begin{array}{l}\text { value of group type at the time of the } \\
\text { reading. }\end{array}$ \\
\hline & & SERIAL ID & $\mathbf{Y}$ & in & 10 & $\begin{array}{l}\text { roreign key - links tips to iten info } \\
\text { table. }\end{array}$ \\
\hline
\end{tabular}




\section{Distribution}

Externa1

J. A. Morley, DOE/DAO

\section{Internal}

G. I. Ball

P. D. Bantz

B. V. Barnhart

R. C. D'Amico

J. F. Edelmann

E. C. Eimutis (5)

W. R. Feairheller

J. W. Gondert

N. A. Guinta

D. R. Hill

T. W. Hughes

C. W. Huntington

T. Z. Jones

D. I. Michaels

D. E. Michel

D. E. Sharp

R. L. Stanley

R. S. Tunning

R. A. Welch

W. D. Williams

H. A. Woltermann

D. A. Zorich

Library (10)

Publications 